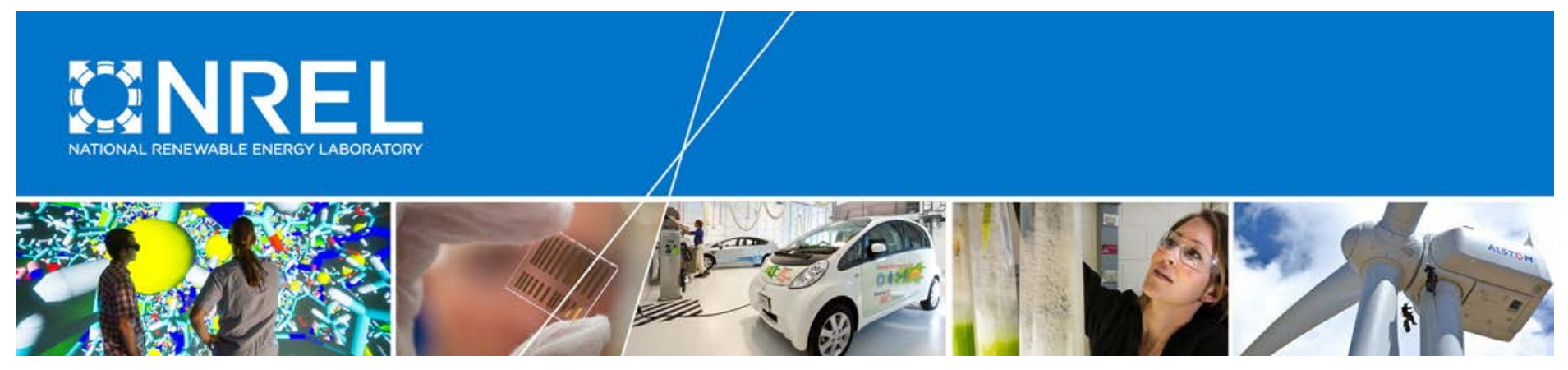

\title{
NREL-Prime Next-Generation Drivetrain Dynamometer Test Report
}

Jonathan Keller

National Renewable Energy Laboratory

Bill Erdman

Cinch, Inc.

Douglas Blodgett

DNV KEMA Renewables

Christopher Halse

Romax Technology

NREL is a national laboratory of the U.S. Department of Energy Office of Energy Efficiency \& Renewable Energy

Operated by the Alliance for Sustainable Energy, LLC

This report is available at no cost from the National Renewable Energy Laboratory (NREL) at www.nrel.gov/publications.

Technical Report

NREL/TP-5000-66350

August 2016

Contract No. DE-AC36-08G028308 


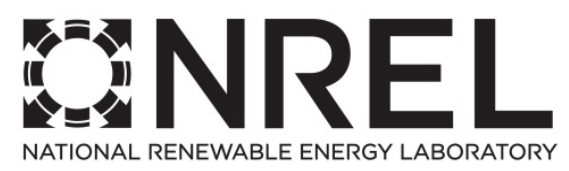

\section{NREL-Prime Next-Generation Drivetrain Dynamometer Test Report}

Jonathan Keller

National Renewable Energy Laboratory

Bill Erdman

Cinch, Inc.

Douglas Blodgett

DNV KEMA Renewables

Christopher Halse

Romax Technology

Prepared under Task No. WE11.3061

NREL is a national laboratory of the U.S. Department of Energy Office of Energy Efficiency \& Renewable Energy Operated by the Alliance for Sustainable Energy, LLC

This report is available at no cost from the National Renewable Energy Laboratory (NREL) at www.nrel.gov/publications.

National Renewable Energy Laboratory 15013 Denver West Parkway Golden, CO 80401

303-275-3000 • www.nrel.gov
Technical Report

NREL/TP-5000-66350

August 2016

Contract No. DE-AC36-08GO28308 


\section{NOTICE}

This report was prepared as an account of work sponsored by an agency of the United States government. Neither the United States government nor any agency thereof, nor any of their employees, makes any warranty, express or implied, or assumes any legal liability or responsibility for the accuracy, completeness, or usefulness of any information, apparatus, product, or process disclosed, or represents that its use would not infringe privately owned rights. Reference herein to any specific commercial product, process, or service by trade name, trademark, manufacturer, or otherwise does not necessarily constitute or imply its endorsement, recommendation, or favoring by the United States government or any agency thereof. The views and opinions of authors expressed herein do not necessarily state or reflect those of the United States government or any agency thereof.

This report is available at no cost from the National Renewable Energy Laboratory (NREL) at www.nrel.gov/publications.

Available electronically at SciTech Connect http:/www.osti.gov/scitech

Available for a processing fee to U.S. Department of Energy and its contractors, in paper, from:

U.S. Department of Energy

Office of Scientific and Technical Information

P.O. Box 62

Oak Ridge, TN 37831-0062

OSTI http://www.osti.gov

Phone: 865.576.8401

Fax: 865.576.5728

Email: reports@osti.gov

Available for sale to the public, in paper, from:

U.S. Department of Commerce

National Technical Information Service

5301 Shawnee Road

Alexandria, VA 22312

NTIS http://www.ntis.gov

Phone: 800.553 .6847 or 703.605 .6000

Fax: 703.605.6900

Email: orders@ntis.gov 


\section{Acknowledgments}

This project is funded by the U.S. Department of Energy through the U.S. Wind Power: Next

Generation Drivetrain Development Funding Opportunity Announcement (DE-FOA-0000439). 


\section{List of Acronyms}

$\begin{array}{ll}\text { AC } & \text { alternating current } \\ \text { BLT } & \text { bearing lubricant temperature } \\ \text { CGI } & \text { controllable grid interface } \\ \text { data acquisition system } & \text { direct current } \\ \text { DAS } & \text { Global Energy Concepts } \\ \text { DC } & \text { International Standards Organization } \\ \text { GEC } & \text { inside end turn } \\ \text { ISO } & \text { kilonewton-meter } \\ \text { IET } & \text { kilowatt } \\ \text { kNm } & \text { liters per minute } \\ \text { kW } & \text { low-voltage ride-through } \\ \text { LPM } & \text { main bearing temperature } \\ \text { LVRT } & \text { millisecond } \\ \text { MBT } & \text { megawatt } \\ \text { ms } & \text { next-generation drivetrain } \\ \text { MW } & \text { National Instruments } \\ \text { NGD } & \text { National Renewable Energy Laboratory } \\ \text { NI } & \text { nontorque load } \\ \text { NREL } & \text { outside end turn } \\ \text { NTL } & \text { positive-negative sequence control } \\ \text { OET } & \text { pounds per square inch } \\ \text { PNSC } & \text { revolutions per minute } \\ \text { psi } & \text { resistance temperature detector } \\ \text { rpm } & \text { volt } \\ \text { RTD } & \text { Wind Partnerships for Advanced Component } \\ \text { V } & \text { Technology } \\ \text { WindPACT } & \end{array}$




\section{Table of Contents}

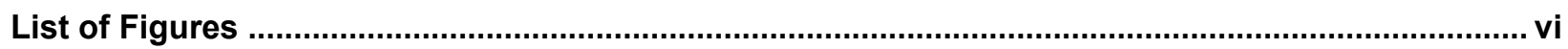

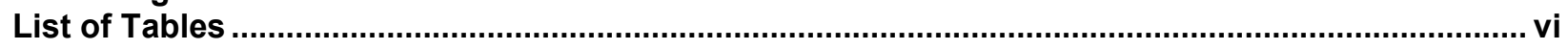

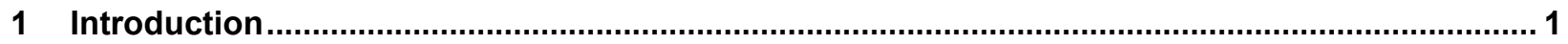

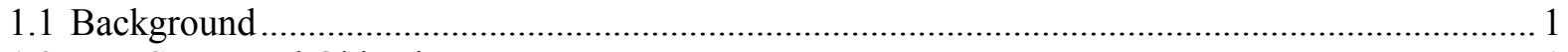

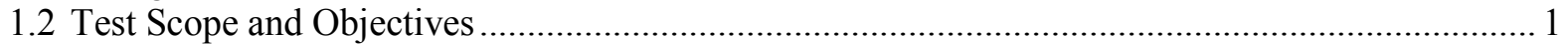

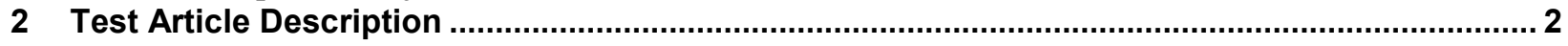

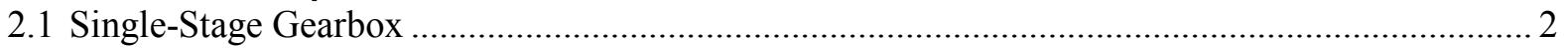

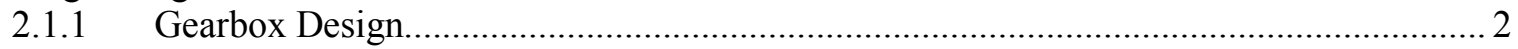

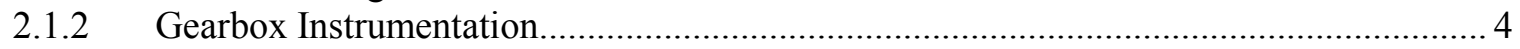

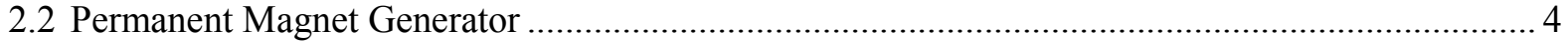

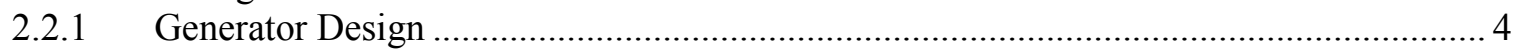

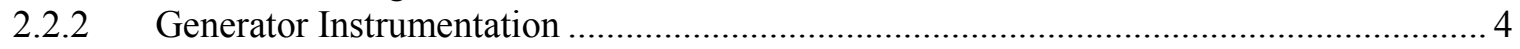

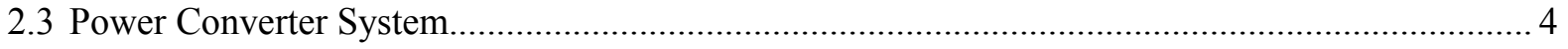

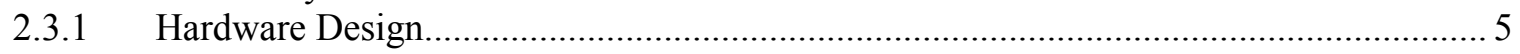

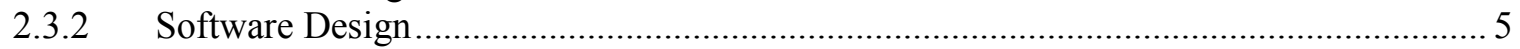

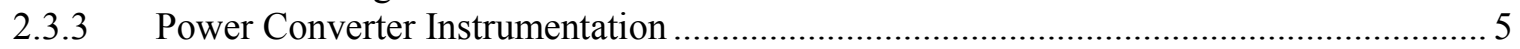

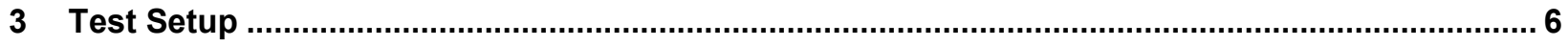

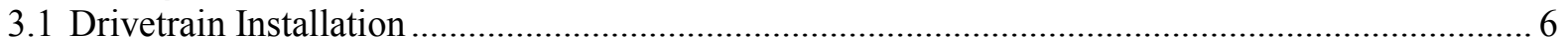

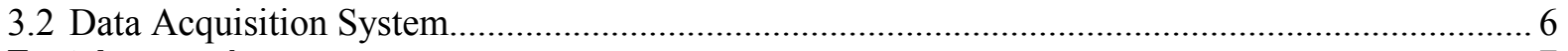

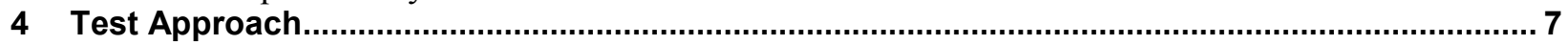

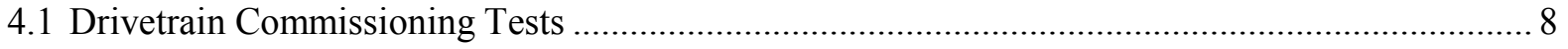

4.2 Gearbox Journal Bearing and Flex Pin Performance Test...................................................... 10

4.3 Power Converter Performance Tests ................................................................................... 14

4.3.1 Main Shaft Torsional Mode Active Damping............................................................... 14

4.3.2 Symmetrical and Asymmetrical Fault Response ................................................... 15

4.3.3 Frequency Deviation Response ........................................................................ 18

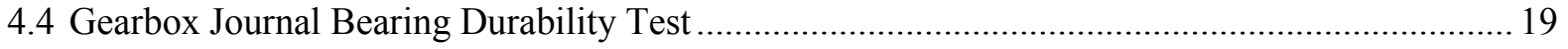

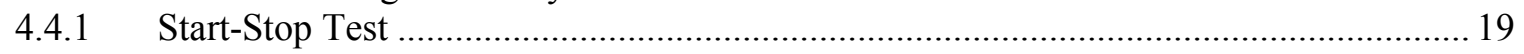

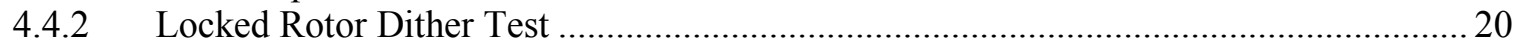

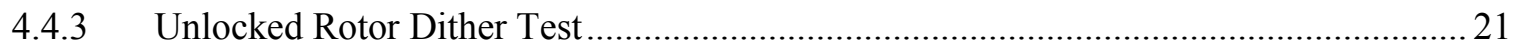

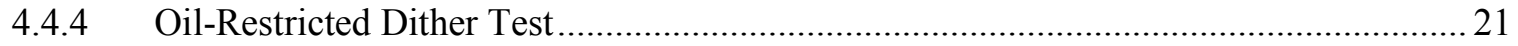

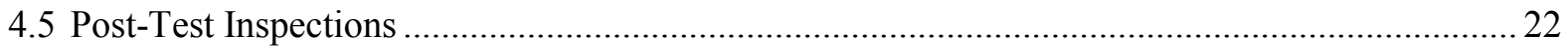

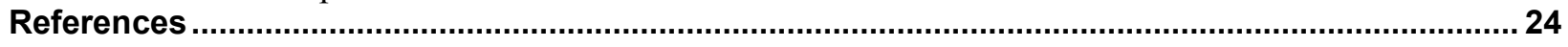

Appendix 


\section{List of Figures}

Figure 1. NGD medium-speed drivetrain. Photo by Jonathan Keller, NREL 35026............................ 2

Figure 2. Gearbox schematic. Illustration by Romax Technology ...................................................... 3

Figure 3. Planetary carrier and spindles (left) and (right) planets. Photos by Jesse Graeter, Romax

Technology, NREL 33353 (left), and Jonathan Keller, NREL 33341 (right)................................. 3

Figure 4. Inverter (left) and major inverter components (right). Photos by DNV KEMA Renewables 5

Figure 5. Schematic of NGD data acquisition system................................................................. 6

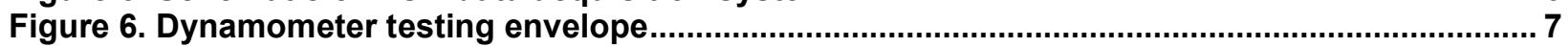

Figure 7. Load Step 6 dynamometer torque oscillations ............................................................. 9

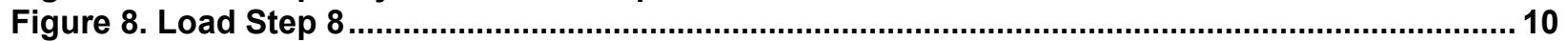

Figure 9. Planet load share at low (left) and high torque (right) [8]. Illustrations by Romax

Technology.

Figure 10. Ring gear tooth face-width load distribution at low torque (left) and high torque (right)

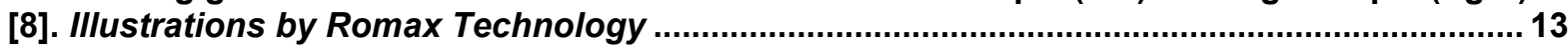

Figure 11. Drivetrain response to step change in power.......................................................... 15

Figure 12. Drivetrain response to a nine-cycle symmetrical LVRT to $12 \%$ of terminal voltage........ 16

Figure 13. Drivetrain response to a 30 -cycle symmetrical LVRT to $50 \%$ of terminal voltage ........... 17

Figure 14. Summary of drivetrain response to LVRT events (left) and worst-case event (right) ..... 18

Figure 15. ISO oil cleanliness counts during start-stop testing [8]. IIIustration by Romax

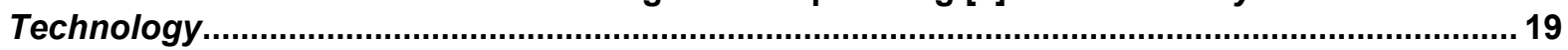

Figure 16. Drivetrain response in locked rotor dither conditions................................................... 20

Figure 17. Unlocked and oil-restricted dither testing. Photo by Mark McDade, NREL 36517........... 22

Figure 18. Sun gear (left), normal planet gear (middle), and fretted planet gear (right)................... 23

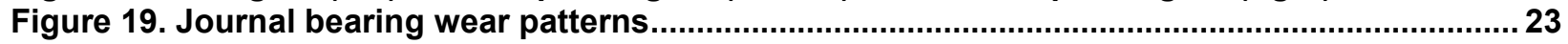

Figure 20. Ring gear tooth instrumentation. Illustration by Romax Technology ............................. 26

Figure 21. Gearbox vibration instrumentation. Illustration by Romax Technology............................27

Figure 22. Flex pin instrumentation. Illustration by Romax Technology .......................................... 28

Figure 23. Journal bearing temperature instrumentation. Illustration by Romax Technology......... 29

Figure 24. Oil supply temperature and pressure instrumentation. IIlustration by Romax

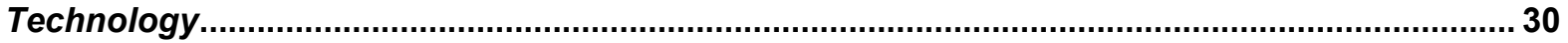

\section{List of Tables}

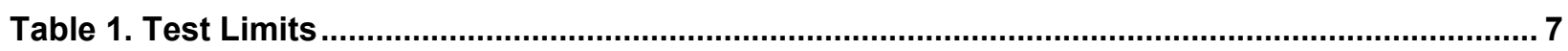

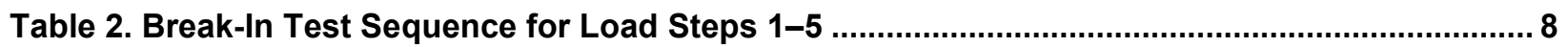

Table 3. Break-In Test Sequence for Load Steps 6-7 …............................................................ 9

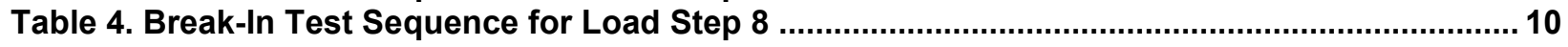

Table 5. Gearbox Functionality Test Sequence \#1-High Speed, Increasing Torque ...................... 11

Table 6. Gearbox Functionality Test Sequence \#2-Medium Speed, Increasing Torque ................. 11

Table 7. Gearbox Functionality Test Sequence \#3-Low Speed, Increasing Torque ......................... 12

Table 8. Gearbox Functionality Test Sequence \#4-Lowest Speed, Increasing Torque................... 12

Table 9. Gearbox Functionality Test Sequence \#5-Constant Power................................................. 13

Table 10. Gearbox Functionality Test Sequence \#6-Constant Torque .............................................. 14

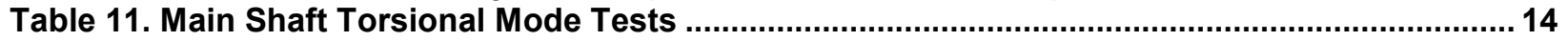

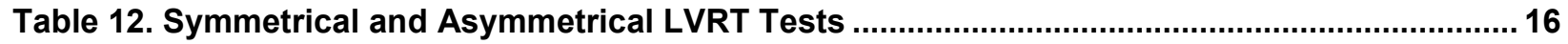

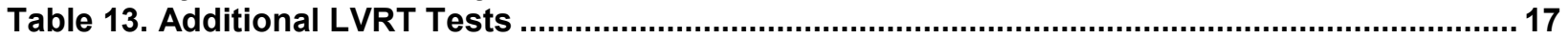

Table 14. Symmetrical High-Voltage Ride-Through Tests............................................................... 18

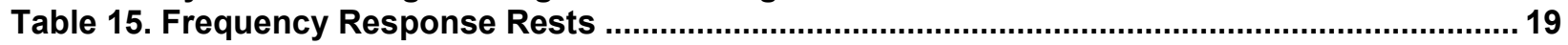

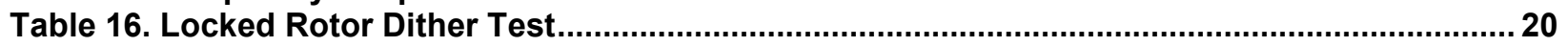

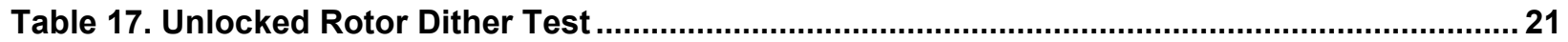

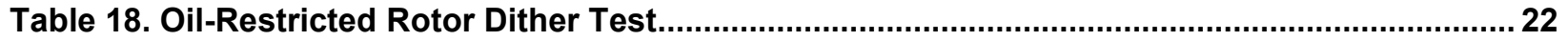

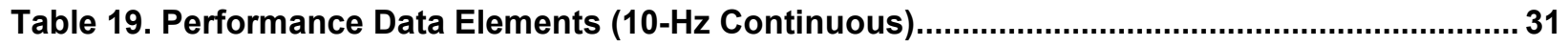

Table 20. "Burst" Data Elements (2 kHz for 60-Second Duration) ..................................................... 33

Table 21. Vibration Condition Monitoring System Data Elements ${ }^{\mathrm{a}}$.................................................. 36

Table 22. Dither Test Data Elements (10-Hz Continuous) .............................................................. 37 


\section{Introduction}

\subsection{Background}

Advances in wind turbine drivetrain technologies are necessary to improve reliability and reduce the cost of energy for land-based and offshore wind turbines. The wind energy industry is exploring a number of different technologies that may improve the reliability and reduce the cost of wind energy, including unconventional speed increasers and unique direct-drive machines. Although these emerging technologies may have the potential to reduce the cost of energy for very large turbines, a solution proposed by the National Renewable Energy Laboratory's (NREL's) Prime Next-Generation Drivetrain (NGD) Team for geared, medium-speed drivetrains has lower costs and avoids many of the risks associated with other configurations. The NRELPrime NGD Team approach combines multiple incremental but important innovations to meet or exceed the U.S. Department of Energy's funding opportunity announcement goals of producing a lighter, more reliable, and more efficient drivetrain design that decreases installed capital costs, levelized replacement and operations and maintenance costs, and the levelized cost of energy [12]. An end-to-end system engineering approach advances the following NGD innovations:

- A single-stage, epicyclic gearbox designed with four planets, flex pins, and a hydrodynamic (journal) bearing system to increase capacity and reliability

- A power converter operated with grid fault-control algorithms that minimize fault torques, thereby improving drivetrain reliability

- Medium-voltage hybrid silicon/silicon-carbide power converter modules that increase efficiency.

One of the objectives of the NREL-Prime NGD Phase II is to complete the detailed design, fabrication, and dynamometer testing of a 750-kilowatt $(\mathrm{kW})$ drivetrain that includes the key gearbox innovations designed by Romax Technology and power converter innovations designed by DNV KEMA Renewables [3-4]. The purpose of this document is to summarize the completed dynamometer test of the NGD in the National Wind Technology Center's 2.5megawatt dynamometer at NREL.

\subsection{Test Scope and Objectives}

The purpose of the NGD dynamometer test was to gather engineering data to validate the engineering models used to design the key innovations in the gearbox and power converter described above. Doing so will advance the technology readiness level of each of the innovations to 6 , defined as system demonstration in a relevant environment (i.e., the dynamometer). Performing this validation through dynamometer testing was the stated goal of the NGD Phase II [5]. Initial dynamometer test results have been reported along with test results for the mediumvoltage hybrid silicon/silicon-carbide power converter modules [6-8]. 


\section{Test Article Description}

The drivetrain for this project was repurposed from the Wind Partnerships for Advanced Component Technology (WindPACT) medium-speed drivetrain project [9]. This drivetrain is also often called the GEC drivetrain because Global Energy Concepts was the original lead design firm, along with Powertrain Engineers, and DRS Electric Power Technologies for the gearbox and generator design, respectively. The original drivetrain was rated for $1.5 \mathrm{MW}$, operating at 75 kilonewton-meter $(\mathrm{kNm})$ of torque and 191 revolutions per minute $(\mathrm{rpm})$ in the generator. During testing of the drivetrain, the generator ran at a steady-state temperature up to only 1.2 MW. This equated to $560 \mathrm{kNm}$ in the main shaft and $60 \mathrm{kNm}$ in the generator. The drivetrain was taken up to $1.5 \mathrm{MW}$ for a brief period, but the temperature did not level out.

In the current project, the WindPACT main shaft, main shaft bearings, main shaft housing, and generator were all reused. The original three-planet gearbox was removed and replaced with the new four-planet NGD gearbox supplied by Romax Technology, which also mounts the planets on flex pins and journal bearings. The power converter with utility-interconnect fault-control algorithms was supplied by DNV KEMA Renewables. The completed NGD drivetrain is shown in Figure 1.

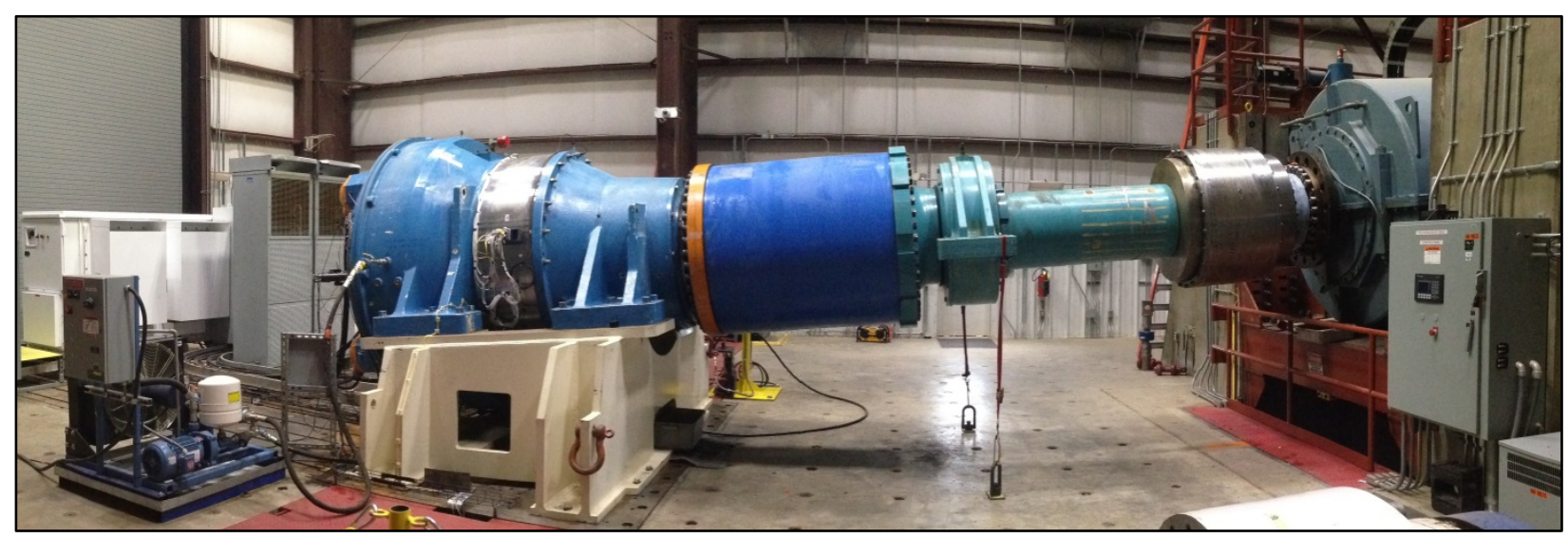

Figure 1. NGD medium-speed drivetrain. Photo by Jonathan Keller, NREL 35026

\subsection{Single-Stage Gearbox}

The gearbox was designed, instrumented, and supplied by Romax Technology. It was manufactured by Brad Foote Gearing, and the journal bearings were supplied by Miba.

\subsubsection{Gearbox Design}

Figure 2 shows the gearbox schematic and design features and Figure 3 shows the planetary section. The gearbox is sandwiched in between the main housing and generator, but it is not directly connected to the bedplate. Within the main housing, the main shaft is supported by a set of LM 283649H 9A4B6 tapered roller bearings (hereafter called the main bearings) in an "O" configuration, and it is directly connected to the planetary carrier in the gearbox through shear pins. The gearbox has four large, spur gear-type planets and an overall ratio of 5.8:1. The sun shaft has a splined connection to the generator rotor through the generator torque tube. 
In addition to the integration of journal bearings and flex pins, the change to four planets necessitated designing and manufacturing a new planet carrier, new sun gear, and, most notably, a new ring gear. The ring gear uses the same dowel and bolt connections to the existing main bearing and generator housings, whereas the carrier uses the same shear pin connection to the main shaft, but additional holes were drilled into the main shaft to allow the carrier to be bolted onto the main shaft prior to installing the planets.

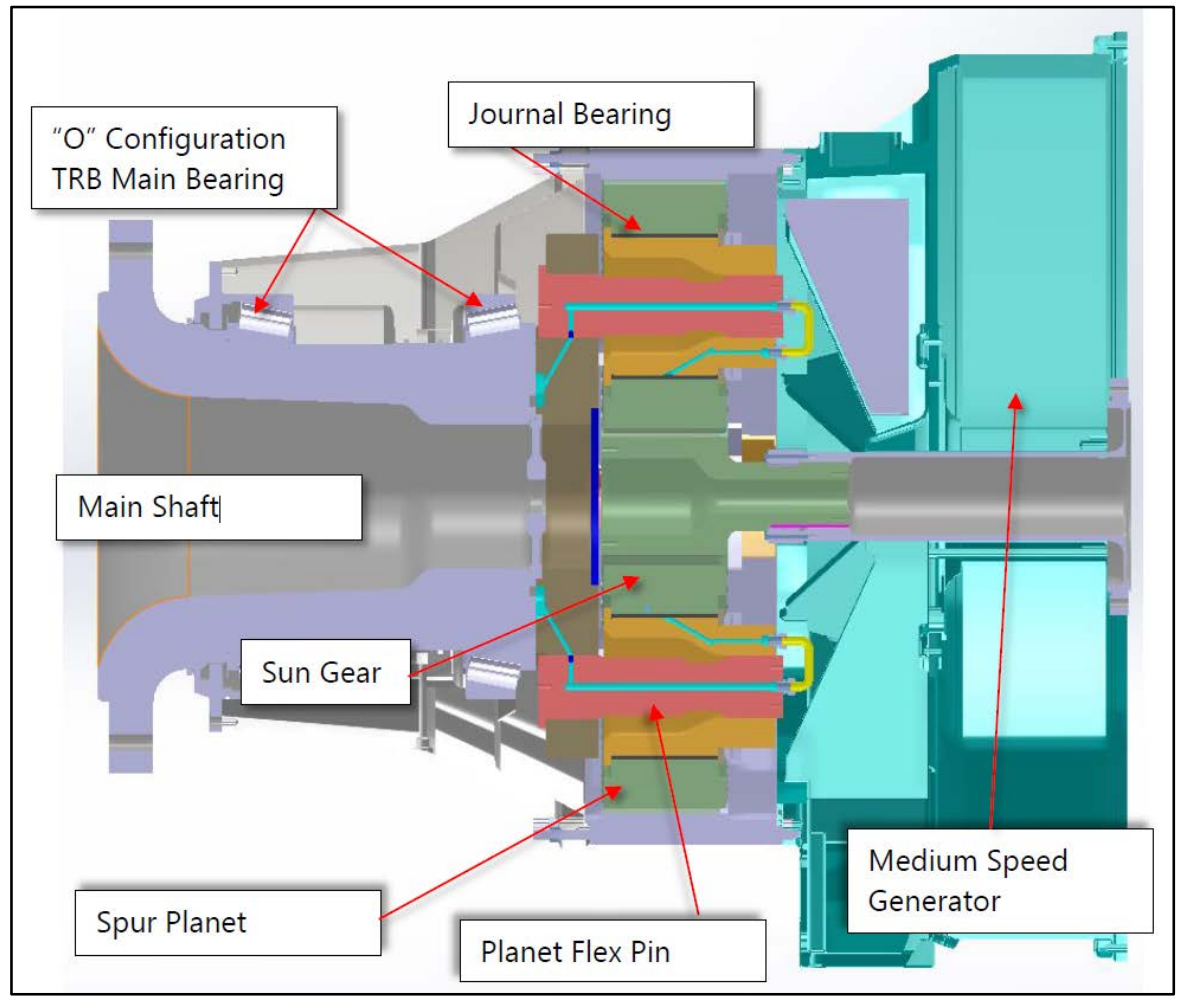

Figure 2. Gearbox schematic. IIlustration by Romax Technology
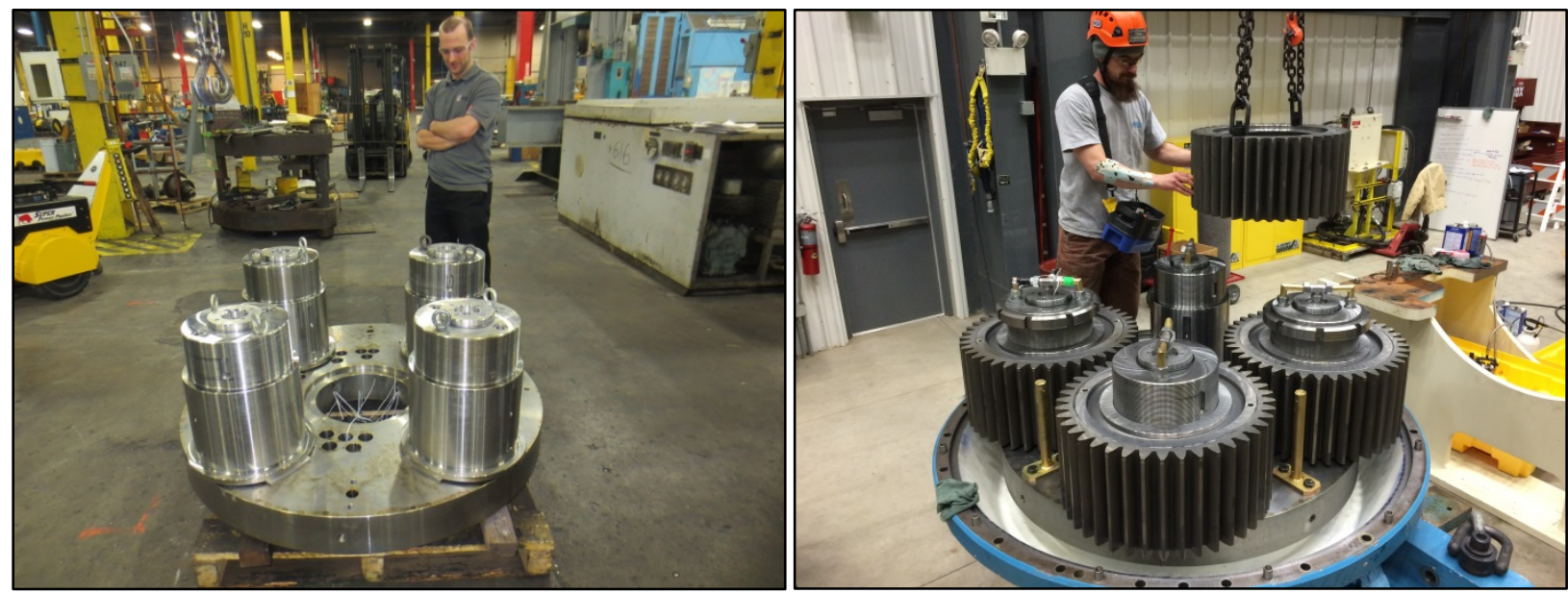

Figure 3. Planetary carrier and spindles (left) and (right) planets. Photos by Jesse Graeter, Romax Technology, NREL 33353 (left), and Jonathan Keller, NREL 33341 (right) 


\subsubsection{Gearbox Instrumentation}

The gearbox was instrumented primarily to measure the load sharing among the planets and to determine the journal bearing performance [10]. The measurement equipment for the proof of operation includes the following:

- Stationary frame

- Ring gear tooth root load distribution in four locations with strain gauges; see Figure 20

- Gearbox vibration with gearbox housing accelerometers; see Figure 21

- Main bearing temperature (MBT) and main bearing lubrication oil temperature (BLT) as installed on the original WindPACT drivetrain

- Oil cleanliness with an oil particle counter measured by a Hydac CSM 1220 oil particle counter.

- Rotating frame

- Bending of all four flex pins with calibrated strain gauges [8]; see Figure 22

- Temperature of all four journal bearings with resistance temperature detectors on the inner surface of each planet spindle, both in the load zone and opposite the load zone; see Figure 23

- Oil supply temperature with a resistance temperature detector (RTD) and oil supply pressure with a pressure transducer to one planet bearing; see Figure 24

- Torque measured on the inner surface of the torque tube with strain gauges as installed on the original WindPACT drivetrain.

\subsection{Permanent-Magnet Generator}

As stated earlier, Phase II was scoped with and enabled by reusing the existing WindPACT medium-speed permanent-magnet generator [9].

\subsubsection{Generator Design}

The generator is a purpose-designed, radial-flux, permanent-magnet synchronous generator. The stator consists of 72 individual poles connected in four discrete quadrants at a "landing"; each quadrant includes all three phases in a star arrangement with an ungrounded neutral. The rotor consists of 48 permanent-magnet poles mounted to the outer rim of a flanged disc. The generator rotor is supported by a pair of SKF 61698 MAVL0241 ball bearings. A bolted connection at the rear of the generator connects the torque tube to the generator rotor.

\subsubsection{Generator Instrumentation}

The inside end turn (IET) and outside end turn (OET) temperatures of the generator windings for four stator segments $(2,4,9$ and 11) were measured by existing three-wire RTDs.

\subsection{Power Converter System}

The power converter system - which consists of a rectifier, transformer, and inverter - and the utility-interconnect software for the inverter were supplied by DNV KEMA Renewables. 


\subsubsection{Hardware Design}

The inverter, shown in Figure 4, was originally designed for an operating voltage range of 300 to 600 volt (V) DC and was repurposed and modified for this project in conjunction with an existing transformer and rectifier. Typically, the inverter portion of a power converter system operates at only one voltage. This would limit the operation of the drivetrain within one speedtorque envelope. For the purposes of this project, multiple speed-torque envelopes were desired to test the journal bearings under high power levels and also under low-speed, high-torque levels. This was achieved by designing the inverter and inverter transformers in three different tap voltages $-100 \mathrm{~V}, 200 \mathrm{~V}$, and $300 \mathrm{~V}$ - changing the inverter software, and separating a single, common DC bus into two separate DC busses to coordinate with the multiwinding permanentmagnet generator.
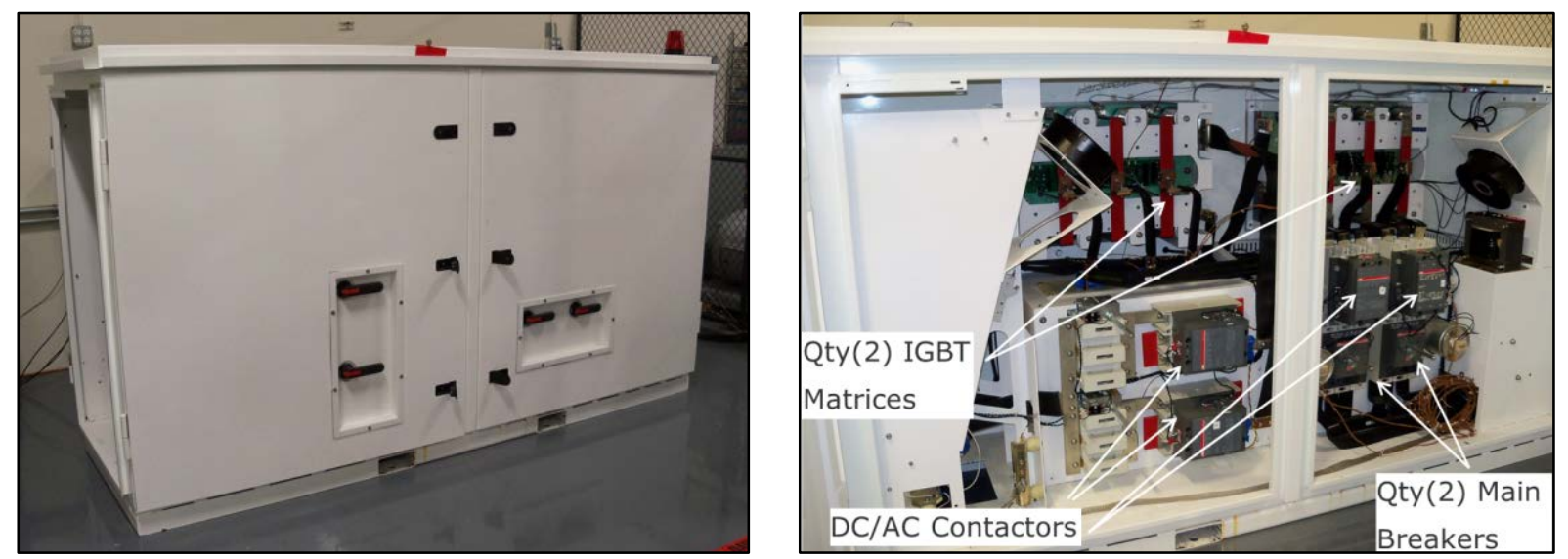

Figure 4. Inverter (left) and major inverter components (right). Photos by DNV KEMA Renewables

\subsubsection{Software Design}

The grid fault-control algorithms and software were developed based on current and anticipated utility-interconnect requirements. These fault-control algorithms were considered not only in the context of their electrical requirements but also with the consideration of utility fault impacts on the single-stage gearbox. It is the intention that these fault-mitigation algorithms will allow for a reduction of the utility curtailments as well as reduced maintenance costs, in particular those related to gearbox problems.

DNV KEMA Renewables developed a control strategy, implemented it in a Powersim model, and simulated fault conditions to determine the impact of the control method on the electromagnetic torque oscillations seen by the generator during these grid faults. The control method known as positive-negative sequence current (PNSC) control eliminates converter DC bus voltage oscillations, and therefore generator torque oscillations, during these transients. A reduction in these torque oscillations is expected to reduce gearbox loads and gearbox failures.

\subsubsection{Power Converter Instrumentation}

Power converter performance measurements were acquired by the same laptop used to control the inverter. In special situations, an oscilloscope was used to acquire high-rate measurements, often for troubleshooting. 


\section{Test Setup}

The National Wind Technology Center's 2.5-MW dynamometer test facility [11] was used for the testing along with the controllable grid interface (CGI) [12].

\subsection{Drivetrain Installation}

The NGD has mechanical and electrical interfaces with the dynamometer facility along with oil lubrication and generator cooling systems as described in the following sections. The electrical, mechanical, and hydraulic setup of the drivetrain was completed in accordance with the test plan [3]. The power converter system and electrical interconnection were inspected and approved for compliance as documented in Inspection Report 00002783ES on April 23, 2015.

\subsection{Data Acquisition System}

The data acquisition system (DAS) is based on National Instruments (NI) deterministic Ethernet platform. Figure 5 shows a general layout of the DAS. One DAS box processes rotating frame signals generated on the planet pins and is mounted to the main shaft adapter. The output of that system is converted to fiber optic and then sent through the conduit tube and across a fiber-optic rotary joint to the stationary frame. The other DAS box processes stationary-frame gear signals. Finally, the torque tube signals are routed through a BN-6 slip ring to the stationary frame. An additional stand-alone vibration monitoring system was provided by Romax Technology.

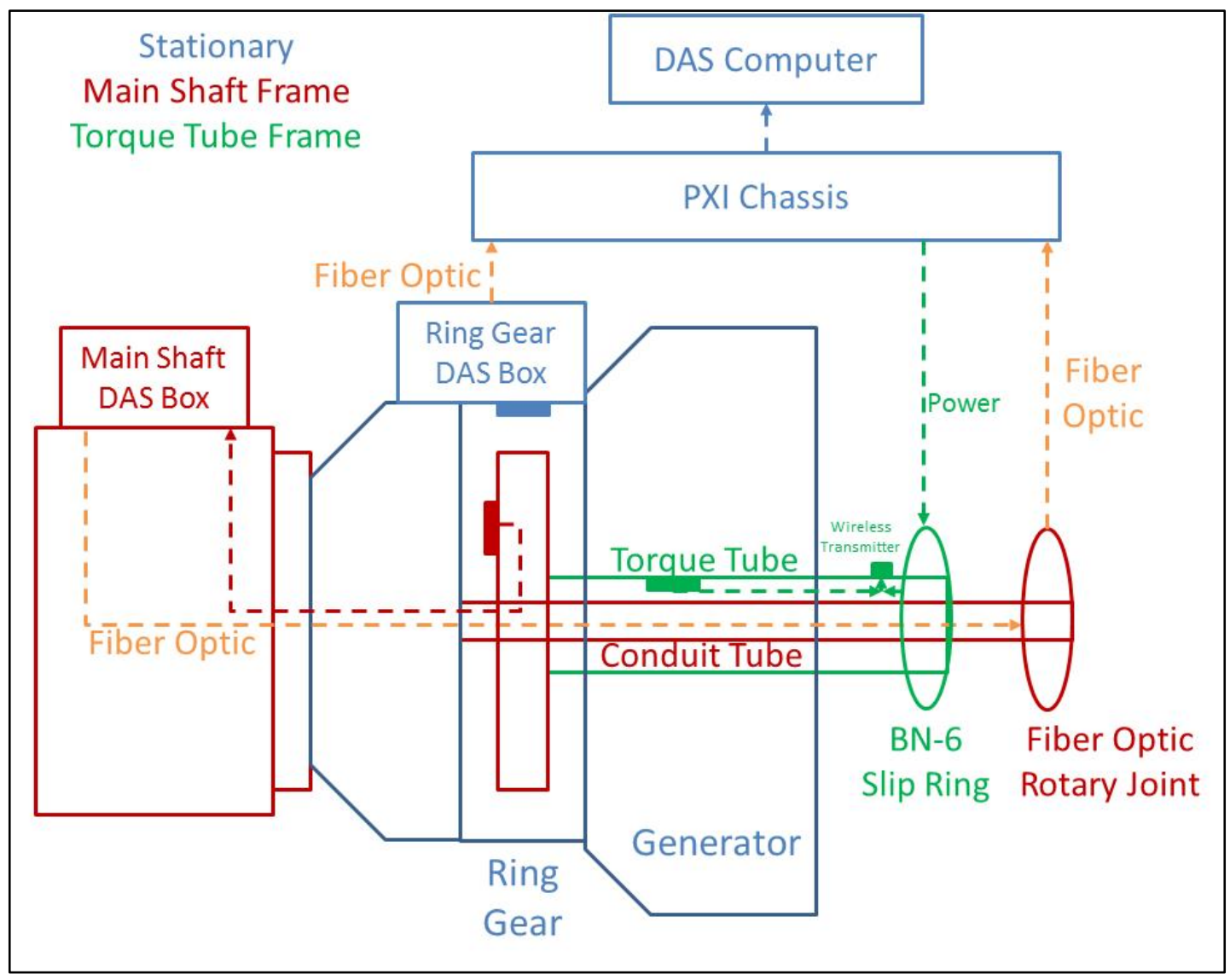

Figure 5. Schematic of NGD data acquisition system 


\section{Test Approach}

Based on previous WindPACT testing and properties of the gearbox and power converter system, the main shaft speed was limited to $13 \mathrm{rpm}$ and the generator speed to $75 \mathrm{rpm}$ during the testing. With the three different tap voltages of $100 \mathrm{~V}, 200 \mathrm{~V}$, and $300 \mathrm{~V}$, the resulting speedtorque envelopes and drivetrain limits for the test are illustrated in Figure 6. At the 200-V tap setting, the estimated maximum power that the drivetrain could produce was $506 \mathrm{~kW}$ of mechanical power and $468 \mathrm{~kW}$ of electrical power, assuming a generator efficiency of $97 \%$.

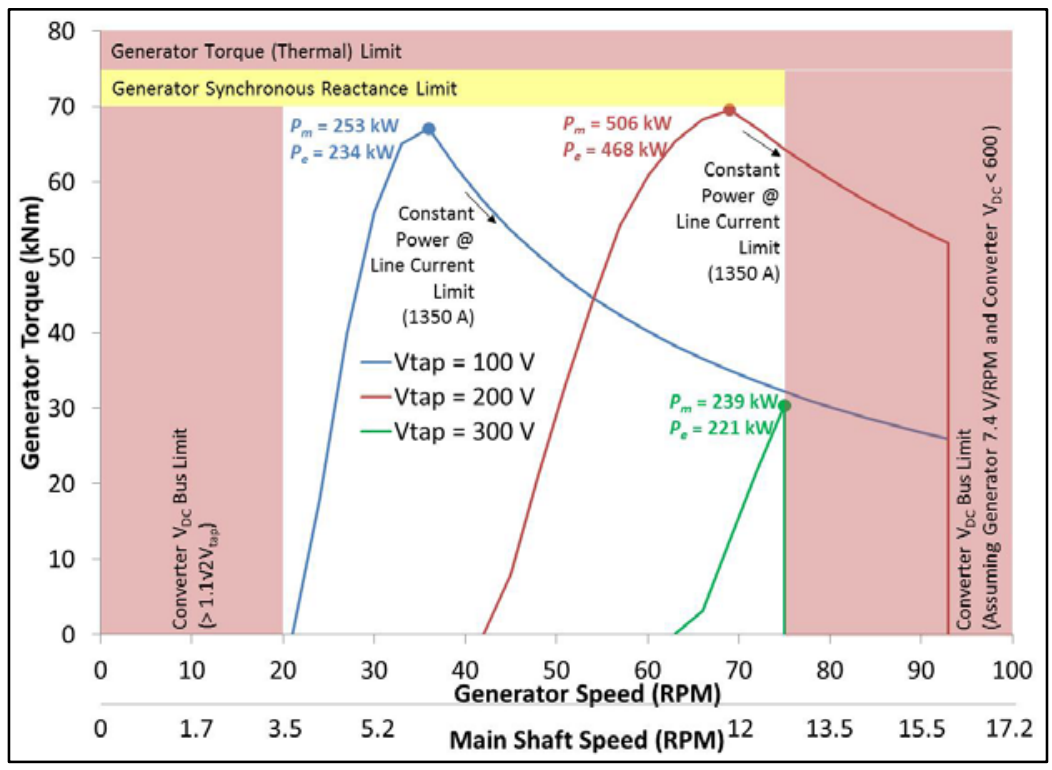

Figure 6. Dynamometer testing envelope

For each of the tests, physical, continuous limits are specified in Table 1, supported by additional documentation of the gearbox mechanical safety factors [13] and the power converter system [14].

Table 1. Test Limits

\begin{tabular}{ccc}
\hline Item & Minimum & Maximum \\
\hline Drivetrain electrical power & & $468 \mathrm{~kW}$ \\
Inverter line current & $3.5 \mathrm{rpm}$ & $13 \mathrm{rpm}$ \\
Main shaft speed & - & $70 \mathrm{kNm}$ \\
Torque tube torque & - & $85^{\circ} \mathrm{C}$ \\
Journal bearing temperature & $60^{\circ} \mathrm{C}$ & $70^{\circ} \mathrm{C}$ \\
Oil sump temperature & - & $10^{\circ} \mathrm{C}$ \\
Journal bearing-to-oil sump temperature difference & - & - \\
Journal bearing oil supply pressure & $1 \mathrm{bar}(14.5 \mathrm{psi})$ & \\
Generator winding temperature & & $170^{\circ} \mathrm{C}$ \\
\hline
\end{tabular}


Testing the NGD occurred in several parts: drivetrain commissioning, gearbox journal bearing and flex pin performance testing, performance testing of the power converter software subject to grid fault conditions, and finally gearbox journal bearing durability testing.

\subsection{Drivetrain Commissioning Tests}

Drivetrain commissioning comprised a series of tasks. It began in late July 2015 with flushing of the drivetrain, verifying the functionality of the generator cooling system, and verifying the instrumentation. Readiness verification was held on August 20, 2015, and authorization to operate was granted per RV_DBY_201508-20. The lubrication system filters were replaced during the gearbox flushing process. The gearbox was operated at $8 \mathrm{rpm}$ for approximately 8 hours to routinely reach a cleanliness of -/14/11. Oil Sample \#1 was taken on September 2, 2015, and sent for analysis. At the time, the cleanliness recorded was 16/14/10. After those activities, the power converter was commissioned by DNV KEMA technicians from September 7-10, 2015.

The next step in the test program was to perform gearbox break-in to wear off gear tooth surface asperities prior to fully loading the gears and bearings. The break-in test was also utilized by Romax personnel to check tooth contact pattern on all the painted gear teeth with a borescope. Break-in of the new gearing began on September 11, 2015. During the first four load steps, the journal bearing temperatures, oil sump temperature, and oil cleanliness stabilized within 30 minutes, but each step was maintained for the 2-hour minimum specified in the test plan. At Load Step 5, approximately 3 hours of run time were needed to reach stabilization, resulting in a total run time of 3 hours and 45 minutes. During each of these load steps, the dynamometer torque was maintained to the desired level within $\pm 5 \mathrm{kNm}$.

Table 2. Break-In Test Sequence for Load Steps 1-5

\begin{tabular}{cccccccc}
\hline Date & $\begin{array}{c}\text { Load Main Shaft } \\
\text { Step }\end{array}$ & $\begin{array}{c}\text { Dynoed } \\
\text { Speed }\end{array}$ & $\begin{array}{c}\text { Torque } \\
(\mathbf{k N m})\end{array}$ & $\begin{array}{c}\text { Generator } \\
\text { Torque } \\
(\mathbf{k N m} / \%)\end{array}$ & $\begin{array}{c}\text { Duration } \\
(\mathbf{h r})\end{array}$ & $\begin{array}{c}\text { Oil Sump } \\
\text { Temp } \\
\left({ }^{\circ} \mathbf{C}\right)\end{array}$ & $\begin{array}{c}\text { Oil } \\
\text { Cleanliness }\end{array}$ \\
\hline Sept. 11 & 1 & $7 / 37 \%$ & 22 & $4 / 5 \%$ & 2 & 52.5 & $16 / 14 / 11$ \\
Sept. 11 & 2 & $10.4 / 80 \%$ & 21 & $3.3 / 5 \%$ & 2 & 56 & $16 / 14 / 10$ \\
Sept. 11 & 3 & $11.9 / 92 \%$ & 22.5 & $3.5 / 5 \%$ & 2 & 57.5 & $17 / 15 / 11$ \\
Sept. 14 & 4 & $11.9 / 92 \%$ & 84 & $13.5 / 20 \%$ & 2 & 50 & $16 / 13 / 9$ \\
Sept. 14 & 5 & $11.9 / 92 \%$ & 167 & $27 / 40 \%$ & 3.75 & 57.5 & $18 / 15 / 11$ \\
\hline
\end{tabular}

On September 15, testing at Load Step 6 began. As the dynamometer torque was increased beyond $150 \mathrm{kNm}$, torque oscillations were noted, as shown in Figure 7. As each torque increment was applied, the oscillations increased in magnitude and lasted longer in duration. At approximately $230 \mathrm{kNm}$, the oscillations began to go unstable, reaching $\pm 40 \mathrm{kNm}$ with a maximum of $270 \mathrm{kNm}$. The desired torque was quickly reduced back to $180 \mathrm{kNm}$, and the oscillations damped out. Upon further examination, the dynamometer and generator torque were oscillating in phase with each other at a frequency of approximately $6.2 \mathrm{~Hz}$, as shown in Figure 7. Note that in this figure the generator torque was multiplied by an arbitrary factor of 6.15 to align it with the dynamometer torque for the purposes of illustration. 


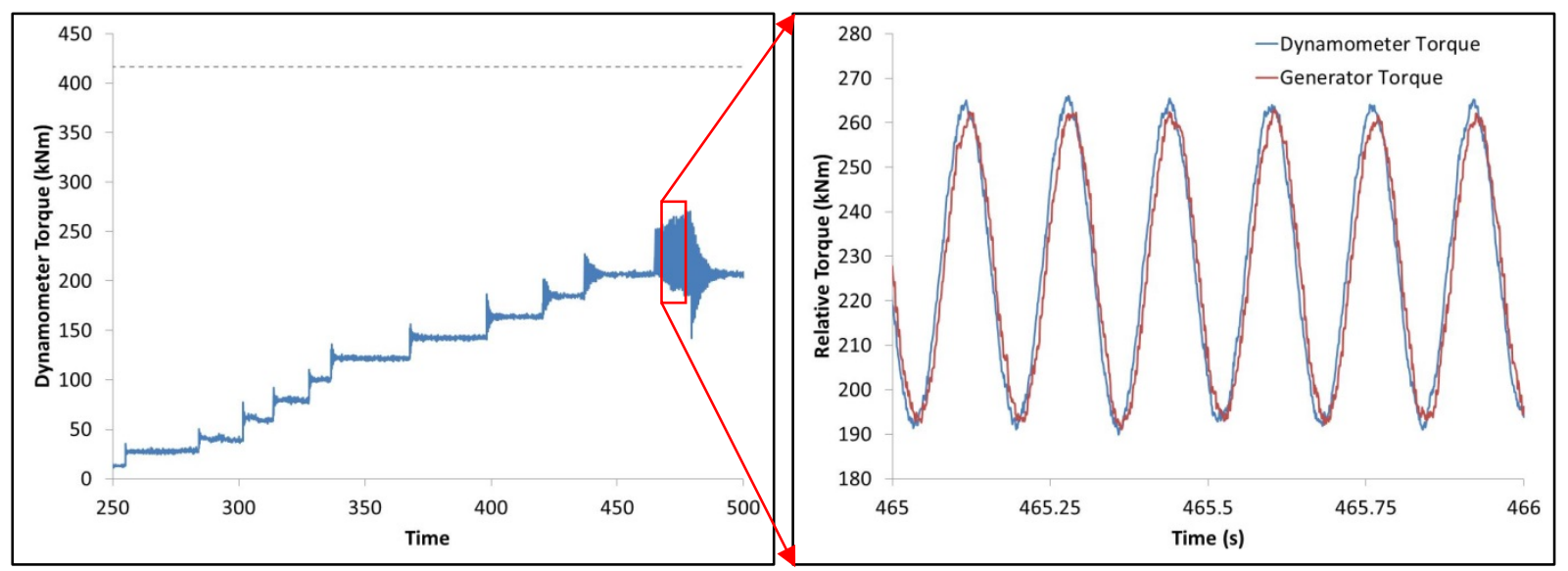

Figure 7. Load Step 6 dynamometer torque oscillations

These results indicate that the entire test article - consisting of the dynamometer shaft, adapters, NGD main shaft, NGD gearbox, and NGD generator - are oscillating together as a single body; therefore, the most likely source of the oscillation is the compliance within the dynamometer gearbox. The natural frequency for a two-inertia, single-torsional spring system with free-free boundary conditions is given by

$$
\omega=\sqrt{\frac{k}{\frac{J_{1} J_{2}}{J_{1}+J_{2}}}}
$$

The total system stiffness $k=60.2 \times 10^{6} \mathrm{~N}-\mathrm{m}$ /radian, which comprises the NGD gearbox, adapter shafting, dynamometer gearbox, and dynamometer-to-motor torque limiter and coupling. The NGD generator inertia $J_{1}=41.6 \times 10^{3} \mathrm{~kg}-\mathrm{m}^{2}$, and the dynamometer motor inertia $J_{2}=650 \times 10^{3}$ $\mathrm{kg}-\mathrm{m}^{2}$. These parameters yield a natural frequency of $6.2 \mathrm{~Hz}$.

A procedure to compensate for the torque oscillations was investigated and implemented on September 15 and 16. The compensation filtered the measured dynamometer torque with a firstorder Butterworth band-pass filter. The filtered torque signal was then multiplied by a gain term of 0.01 and then added to the speed command for the dynamometer motor. In this manner, Load Step 6 and Load Step 7 were achieved on September 16 and 17.

Table 3. Break-In Test Sequence for Load Steps 6-7

\begin{tabular}{cccccccc}
\hline Date & $\begin{array}{c}\text { Load Main Shaft } \\
\text { Step }\end{array}$ & $\begin{array}{c}\text { Dyno } \\
\text { Speed } \\
(\mathbf{r p m} / \%)\end{array}$ & $\begin{array}{c}\text { Torque } \\
(\mathbf{k N m})\end{array}$ & $\begin{array}{c}\text { Generator } \\
\text { Torque } \\
(\mathbf{k N m} / \%)\end{array}$ & $\begin{array}{c}\text { Duration } \\
\mathbf{( h r )}\end{array}$ & $\begin{array}{c}\text { Oil Sump } \\
\text { Temp } \\
\left({ }^{\circ} \mathbf{C}\right)\end{array}$ & $\begin{array}{c}\text { Oil } \\
\text { Cleanliness }\end{array}$ \\
\hline Sept. 16 & 6 & $11.9 / 92 \%$ & 250 & $42 / 60 \%$ & 2 & 57.5 & $18 / 15 / 11$ \\
Sept. 17 & 7 & $11.9 / 92 \%$ & 334 & $56 / 80 \%$ & 2.5 & 56.5 & $18 / 15 / 11$ \\
\hline
\end{tabular}

Load Step 8 was attempted on September 17, but the compensation methodology did not prevent the torque oscillations from occurring above $400 \mathrm{kNm}$. When the full torque of $417 \mathrm{kNm}$ was commanded, unstable oscillations reaching $650 \mathrm{kNm}(160 \%$ rated) occurred. Further 
investigation revealed that the dynamometer motor control parameters were too tightly restricted, and allowing the dynamometer motor to respond more quickly on October 16 significantly damped the torque oscillations. In addition, the two parallel, resistive load banks connecting the generator and rectifier were modified on October 26 to decrease their resistance from 50 Ohms to $22.5 \mathrm{Ohms}$ each to increase electrical damping. In this manner, Load Step 8 at the rated torque of $417 \mathrm{kNm}$ was achieved and completed without incident on October 27, as shown in Figure 8. At the conclusion of the break-in tests, oil samples \#2-\#5were sent for analysis.

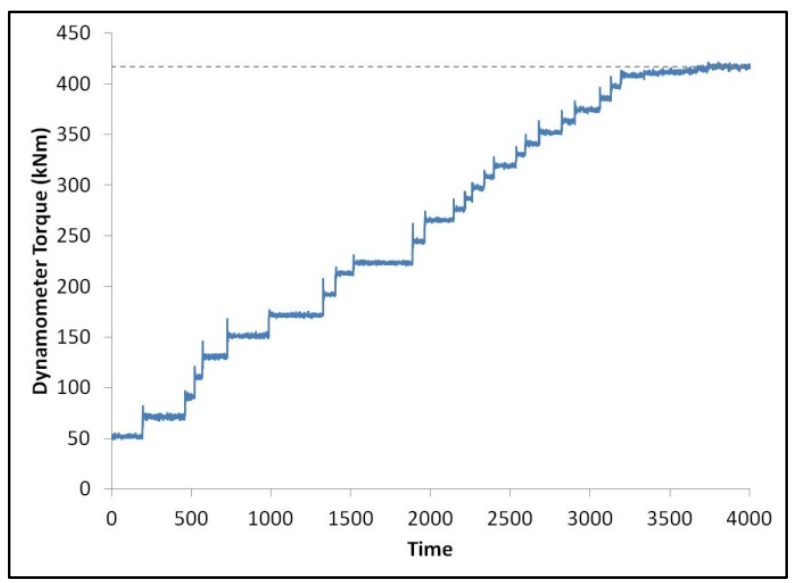

Figure 8. Load Step 8

Table 4. Break-In Test Sequence for Load Step 8

\begin{tabular}{cccccccc}
\hline Date & $\begin{array}{c}\text { Load Main Shaft } \\
\text { Step }\end{array}$ & $\begin{array}{c}\text { Dyno } \\
\text { Speed } \\
(\mathbf{r p m} / \%)\end{array}$ & $\begin{array}{c}\text { Torque } \\
(\mathbf{k N m})\end{array}$ & $\begin{array}{c}\text { Generator } \\
\text { Torque } \\
(\mathbf{k N m} / \%)\end{array}$ & $\begin{array}{c}\text { Duration } \\
(\mathbf{h r})\end{array}$ & $\begin{array}{c}\text { Oil Sump } \\
\text { Temp } \\
\left({ }^{\circ} \mathrm{C}\right)\end{array}$ & Oil \\
Cleanliness \\
\hline Oct. 27 & 8 & $11.9 / 92 \%$ & 417 & $70 / 100 \%$ & 2 & 53.5 & $17 / 15 / 11$ \\
\hline
\end{tabular}

\subsection{Gearbox Journal Bearing and Flex Pin Performance Test}

Gearbox performance testing began with operating the drivetrain at a variety of steady-state speed and torque conditions. The specific goal of these test sequences was to verify the performance of the gearbox compared to the design calculations for planet load share, ring gear tooth load distribution, journal bearing lubrication film thickness and temperature, and planet flex pin deflection. A series of six test sequences were completed as described below. Test Sequence \#1 and Test Sequence \#2 were at high-speed settings and were completed as originally specified. 
Table 5. Gearbox Functionality Test Sequence \#1-High Speed, Increasing Torque

\begin{tabular}{lccccccc}
\hline Date & $\begin{array}{c}\text { Load Main Shaft } \\
\text { Step }\end{array}$ & $\begin{array}{c}\text { Dynoed } \\
\text { (rpm/\%) }\end{array}$ & $\begin{array}{c}\text { Torque } \\
(\mathbf{k N m})\end{array}$ & $\begin{array}{c}\text { Generator } \\
\text { Torque } \\
(\mathbf{k N m} / \%)\end{array}$ & $\begin{array}{c}\text { Duration } \\
\text { (hr) }\end{array}$ & $\begin{array}{c}\text { Oil Sump } \\
\text { Temp } \\
\left({ }^{\circ} \mathbf{C}\right)\end{array}$ & $\begin{array}{c}\text { Oil } \\
\text { Cleanliness }\end{array}$ \\
\hline Oct. 28 & 1 & $13 / 100 \%$ & 83 & $14 / 20 \%$ & $1 / 2$ & 48.0 & $16 / 13 / 9$ \\
Oct. 28 & 2 & $13 / 100 \%$ & 167 & $28 / 40 \%$ & $1 / 2$ & 49.5 & $16 / 14 / 10$ \\
Oct. 28 & 3 & $13 / 100 \%$ & 250 & $42 / 60 \%$ & $1 / 2$ & 51.1 & $17 / 14 / 11$ \\
Oct. 28 & 4 & $13 / 100 \%$ & 334 & $56 / 80 \%$ & $1 / 2$ & 52.9 & $16 / 14 / 10$ \\
Oct. 28 & 5 & $13 / 100 \%$ & 382 & $64.5 / 92 \%$ & $1 / 2$ & 54.7 & $16 / 14 / 10$ \\
Oct. 28 & 6 & $11.9 / 92 \%$ & 417 & $70 / 100 \%$ & $1 / 2$ & 55.0 & $18 / 15 / 10$ \\
\hline
\end{tabular}

Table 6. Gearbox Functionality Test Sequence \#2-Medium Speed, Increasing Torque

\begin{tabular}{lccccccc}
\hline Date & $\begin{array}{c}\text { Load Main Shaft } \\
\text { Step }\end{array}$ & $\begin{array}{c}\text { Dynoed } \\
\text { (rpm/\%) }\end{array}$ & $\begin{array}{c}\text { Torque } \\
(\mathbf{k N m})\end{array}$ & $\begin{array}{c}\text { Generator } \\
\text { Torque } \\
(\mathbf{k N m} / \%)\end{array}$ & $\begin{array}{c}\text { Duration } \\
(\mathbf{h r})\end{array}$ & $\begin{array}{c}\text { Oil Sump } \\
\text { Temp } \\
\left({ }^{\circ} \mathbf{C}\right)\end{array}$ & $\begin{array}{c}\text { Oil } \\
\text { Cleanliness }\end{array}$ \\
\hline Oct. 29 & 1 & $11.9 / 92 \%$ & 83 & $14 / 20 \%$ & $1 / 2$ & 51.5 & $15 / 12 / 8$ \\
Oct. 29 & 2 & $11.9 / 92 \%$ & 167 & $28 / 40 \%$ & $1 / 2$ & 52.5 & $16 / 13 / 8$ \\
Oct. 29 & 3 & $11.9 / 92 \%$ & 250 & $42 / 60 \%$ & $1 / 2$ & 54.2 & $16 / 13 / 8$ \\
Oct. 29 & 4 & $11.9 / 92 \%$ & 334 & $56 / 80 \%$ & $1 / 2$ & 55.5 & $16 / 13 / 8$ \\
Oct. 29 & 5 & $11.9 / 92 \%$ & 417 & $70 / 100 \%$ & $1 / 2$ & 56.0 & $18 / 15 / 10$ \\
\hline
\end{tabular}

A comparison of the effect of drivetrain torque is shown in Figure 9 for Test Sequence \#2. The general trend is that the planet load share improves (becomes more equal) as torque is increased, as noted during this test sequence and other sequences [8]. At the lowest torque of $83 \mathrm{kNm}$, the planet load share is as much as 0.15 different; whereas at rated torque of $417 \mathrm{kNm}$, that difference drops to 0.04 .
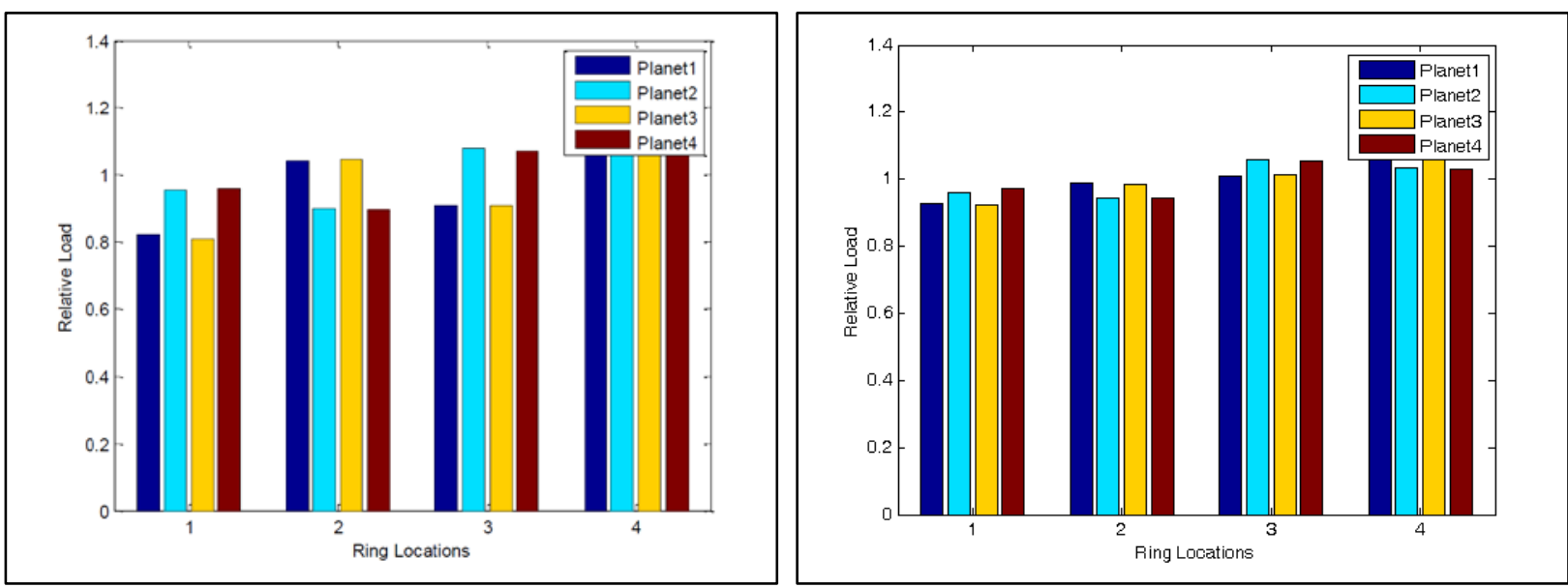

Figure 9. Planet load share at low (left) and high torque (right) [8]. Illustrations by Romax Technology 
On October 30, Test Sequence \#3 began by operating the drivetrain at a lower speed and stepping up to high torque levels. These conditions are the most challenging for the journal bearings. At Load Step \#3, the oil cleanliness level reached 19/16/10, higher than the desired -/15/12. After consulting with Romax Technology, an oil cleanliness level of -/16/12 was deemed acceptable for continued testing. Testing resumed on November 9, and the first three load steps were achieved without issue. However, when transitioning to Load Step 4, another torque oscillation was encountered. The torque compensation filtering parameters were adjusted, and the fourth load step was achieved. When transitioning to Load Step 5, the oscillation occurred again, and attempts to compensate for it were not successful. At this point, the test sequence was concluded. The next day, Test Sequence \#4 was completed at the lowest speed as originally specified.

\begin{tabular}{|c|c|c|c|c|c|c|c|}
\hline Date & $\begin{array}{l}\text { Load } \\
\text { Step }\end{array}$ & $\begin{array}{c}\text { Main Shaft } \\
\text { Speed } \\
\text { (rpm/\%) }\end{array}$ & $\begin{array}{c}\text { Dyno } \\
\text { Torque } \\
\text { (kNm) }\end{array}$ & $\begin{array}{c}\text { Generator } \\
\text { Torque } \\
\text { (kNm/\%) }\end{array}$ & $\begin{array}{l}\text { Duration } \\
\text { (hr) }\end{array}$ & $\begin{array}{l}\text { Oil Sump } \\
\text { Temp } \\
\left({ }^{\circ} \mathrm{C}\right)\end{array}$ & $\begin{array}{c}\text { Oil } \\
\text { Cleanliness }\end{array}$ \\
\hline Nov. 9 & 1 & $6.2 / 48 \%$ & 79 & $13.4 / 19 \%$ & $1 / 2$ & 46.9 & $15 / 12 / 7$ \\
\hline Nov. 9 & 2 & $6.2 / 48 \%$ & 159 & $26.8 / 38 \%$ & $1 / 2$ & 48.3 & $16 / 13 / 7$ \\
\hline Nov. 9 & 3 & $6.2 / 48 \%$ & 238 & $40.2 / 57 \%$ & $1 / 2$ & 49.9 & 17/14/8 \\
\hline Nov. 9 & 4 & $6.2 / 48 \%$ & 318 & $53.6 / 77 \%$ & $1 / 2$ & 53.0 & $19 / 16 / 10$ \\
\hline- & 5 & $6.2 / 48 \%$ & 397 & $67 / 96 \%$ & - & - & - \\
\hline
\end{tabular}

Table 8. Gearbox Functionality Test Sequence \#4-Lowest Speed, Increasing Torque

\begin{tabular}{cccccccc}
\hline Date & $\begin{array}{c}\text { Load Main Shaft } \\
\text { Step }\end{array}$ & $\begin{array}{c}\text { Speed } \\
\text { (rpm/\%) }\end{array}$ & $\begin{array}{c}\text { Dorque } \\
\text { Torque } \\
(\mathbf{k N m})\end{array}$ & $\begin{array}{c}\text { Generator } \\
\text { Torque } \\
(\mathbf{k N m} / \%)\end{array}$ & $\begin{array}{c}\text { Duration } \\
\text { (hr) }\end{array}$ & $\begin{array}{c}\text { Oil Sump } \\
\text { Temp } \\
\left({ }^{\circ} \mathbf{C}\right)\end{array}$ & $\begin{array}{c}\text { Oil } \\
\text { Cleanliness }\end{array}$ \\
\hline Nov. 10 & 1 & $4.1 / 32 \%$ & 53 & $9 / 13 \%$ & $1 / 2$ & 46.3 & $15 / 12 / 8$ \\
Nov. 10 & 2 & $4.1 / 32 \%$ & 107 & $18 / 26 \%$ & $1 / 2$ & 46.9 & $16 / 13 / 7$ \\
\hline
\end{tabular}

Analysis shows that the ring gear tooth face width-load distribution shifts downwind as torque increases, as shown in Figure 10 from Test Sequence \#3. This trend was also noted in the borescope images of the gearbox [8]. 

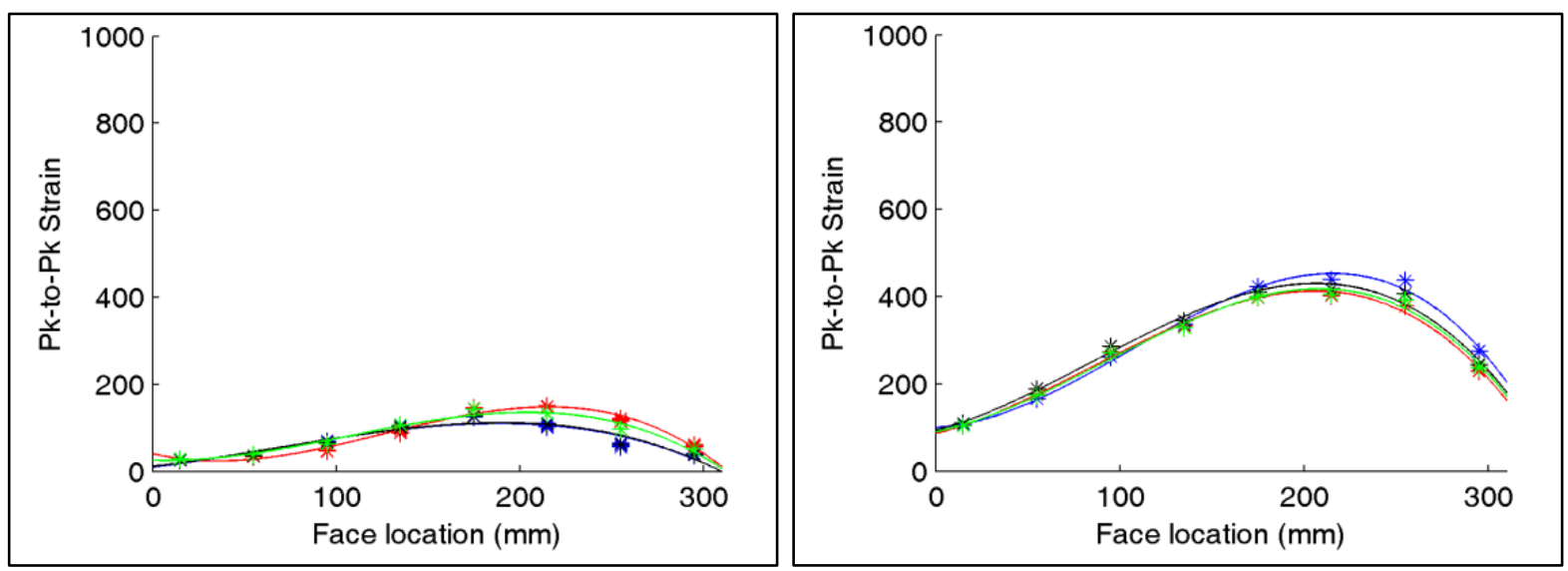

Figure 10. Ring gear tooth face-width load distribution at low torque (left) and high torque (right) [8]. Illustrations by Romax Technology

On November 10, Test Sequence \#5 began by operating the drivetrain at constant power and varying torque and speed. Because of the previously noted torque oscillation at $6.2 \mathrm{rpm}$ above $330 \mathrm{kNm}$ torque, Load Step 4 was skipped; otherwise, the test was completed as specified. Test Sequence \#6, the last gearbox performance test, was completed on November 11 as specified. At the conclusion of the functionality tests, the contact pattern on all the painted gear teeth was borescope inspected by Romax personnel, and oil samples \#6-\#11 were sent for analysis.

Table 9. Gearbox Functionality Test Sequence \#5-Constant Power

\begin{tabular}{cccccccc}
\hline Date & $\begin{array}{c}\text { Load } \\
\text { Step }\end{array}$ & $\begin{array}{c}\text { Speed } \\
\text { (rpm/\%) }\end{array}$ & $\begin{array}{c}\text { Dorque } \\
\text { (kNm) })\end{array}$ & $\begin{array}{c}\text { Generator } \\
\text { Torque } \\
(\mathbf{k N m} / \%)\end{array}$ & $\begin{array}{c}\text { Duration } \\
\mathbf{( h r})\end{array}$ & $\begin{array}{c}\text { Oil Sump } \\
\text { Temp } \\
\left({ }^{\circ} \mathbf{C}\right)\end{array}$ & $\begin{array}{c}\text { Oil } \\
\text { Cleanliness }\end{array}$ \\
\hline Nov. 10 & 1 & $13 / 100 \%$ & 190 & $32 / 46 \%$ & $1 / 2$ & 49.1 & $15 / 13 / 9$ \\
Nov. 10 & 2 & $9.5 / 73 \%$ & 261 & $44 / 63 \%$ & $1 / 2$ & & $15 / 12 / 8$ \\
Nov. 10 & 3 & $7.5 / 58 \%$ & 326 & $55 / 79 \%$ & $1 / 2$ & & $17 / 15 / 9$ \\
- & 4 & $6.2 / 48 \%$ & 397 & $67 / 96 \%$ & - & - & - \\
Nov. 10 & 5 & $7.5 / 58 \%$ & 326 & $55 / 79 \%$ & $1 / 2$ & 54.5 & $17 / 15 / 9$ \\
Nov. 10 & 6 & $9.5 / 73 \%$ & 261 & $44 / 63 \%$ & $1 / 2$ & 55.8 & $17 / 14 / 7$ \\
Nov. 10 & 7 & $13 / 100 \%$ & 190 & $32 / 46 \%$ & $1 / 2$ & 56.0 & $17 / 14 / 10$ \\
\end{tabular}


Table 10. Gearbox Functionality Test Sequence \#6-Constant Torque

\begin{tabular}{lccccccc}
\hline Date & $\begin{array}{c}\text { Load } \\
\text { Step }\end{array}$ & $\begin{array}{c}\text { Main Shaft } \\
\text { Speed } \\
(\mathbf{r p m} / \%)\end{array}$ & $\begin{array}{c}\text { Dyno } \\
\text { Torque } \\
(\mathbf{k N m})\end{array}$ & $\begin{array}{c}\text { Generator } \\
\text { Torque } \\
\mathbf{( k N m / \% )}\end{array}$ & $\begin{array}{c}\text { Duration } \\
\mathbf{( h r})\end{array}$ & $\begin{array}{c}\text { Oil Sump } \\
\text { Temp } \\
\left({ }^{\circ} \mathbf{C}\right)\end{array}$ & $\begin{array}{c}\text { Oil } \\
\text { Cleanliness }\end{array}$ \\
\hline Nov. 11 & 1 & $13 / 100 \%$ & 379 & $64 / 91 \%$ & $1 / 2$ & 52.0 & $18 / 15 / 11$ \\
Nov. 11 & 2 & $11.9 / 92 \%$ & 379 & $64 / 91 \%$ & $1 / 2$ & 54.6 & $17 / 13 / 9$ \\
Nov. 11 & 3 & $10.8 / 83 \%$ & 379 & $64 / 91 \%$ & $1 / 2$ & 55.4 & $17 / 13 / 8$ \\
Nov. 11 & 4 & $11.9 / 92 \%$ & 379 & $64 / 91 \%$ & $1 / 2$ & 55.9 & $18 / 15 / 10$ \\
Nov. 11 & 5 & $13 / 100 \%$ & 379 & $64 / 91 \%$ & $1 / 2$ & 56.0 & $17 / 14 / 9$ \\
\hline
\end{tabular}

\subsection{Power Converter Performance Tests}

Symmetrical and asymmetrical faults are intense sources of excitation for natural torsional resonances in the drivetrain that can result in damaging speed and torque oscillations. The PNSC method uses power converter DC-link voltage sensing to provide active damping of the most significant of these torsional modes [14]. The power converter performance tests began by determining the main shaft torsional mode, followed by testing several types of utility faults derived from U.S. [15] and international requirements [16]. The goals of these tests were to measure drivetrain response to fault conditions for comparison to models and then, if possible, verify the ability of the PNSC algorithm to reduce generator torque during such conditions.

\subsubsection{Main Shaft Torsional Mode Active Damping}

The first step in this process was to determine the frequency of the main shaft torsional mode through measurements because it serves as input to the torsional mode rejection software. The second step was to perform a dedicated damping test using the inverter control software. The main shaft torsional mode was measured on November 11 through small but fast drivetrain power/torque oscillations. The test was completed at full speed (13 rpm on the main shaft) and beginning at full torque ( $417 \mathrm{kNm}$ on the main shaft) with the dynamometer torque compensation enabled. Using the inverter control software, three downward steps in power were commanded of approximately $125 \mathrm{~kW}$ each, as listed in Table 11 . The resulting main shaft behavior during the first step is shown in Figure 11. The torque oscillations occur at $6.2 \mathrm{~Hz}$, as previously noted. The step in measured power relates to the $20-\mathrm{Hz}$ data refresh rate of the measurement.

Table 11. Main Shaft Torsional Mode Tests

\begin{tabular}{ccc}
\hline Date & Disturbance & $\begin{array}{c}\text { Inverter } \\
\text { Damping }\end{array}$ \\
\hline Nov. 11 & Three step changes in commanded electrical power of $125 \mathrm{~kW}$ each & Disabled \\
\hline
\end{tabular}




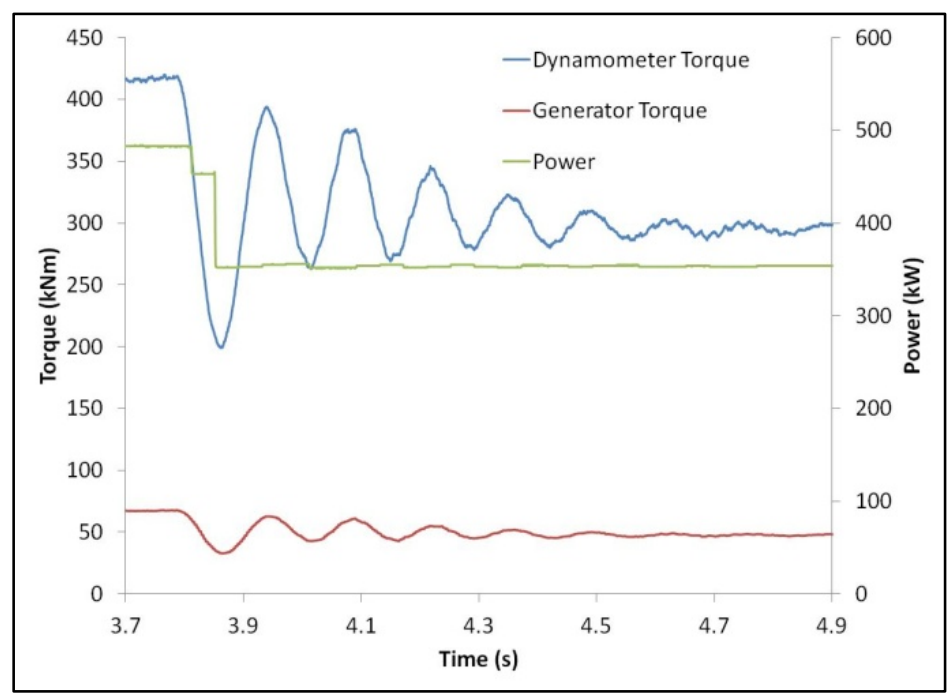

Figure 11. Drivetrain response to step change in power

\subsubsection{Symmetrical and Asymmetrical Fault Response}

Power and torque transients associated with symmetrical (three-phase) and asymmetrical (singlephase) grid faults were characterized under a variety of fault conditions in this test sequence. For symmetrical faults, the PNSC method automatically reverts to a second control method known as balanced positive-sequence control. This method generates symmetrical currents in response to both balanced and unbalanced line voltages. For asymmetrical faults, the PNSC method generates high-quality asymmetrical output current waveforms that cancel the second harmonic component of active power and torque oscillations in the drivetrain.

Once the torsional mode was determined on November 11, as described in the previous section, the first utility faults were emulated using the CGI. Initial low-voltage ride-through (LVRT) tests on November 17 were intended to confirm proper operation of the inverter when interacting with the CGI. The LVRT faults tested were both three-phase (symmetrical) and single-phase (asymmetrical) faults ranging from $75 \%$ to $90 \%$ of terminal voltage for $1 / 2$ second ( 30 cycles) but at different main shaft speed and electrical power conditions. The fault tests continued on November 18. In these tests, the drivetrain was always operated at $10 \mathrm{rpm}$ but at a range of torque and electrical power conditions. The tests proceeded in a graduated fashion, incrementally lowering the percentage of terminal voltage. For tests at less than $65 \%$ of terminal voltage, an electrical issue in the inverter prevented it from remaining connected to the CGI. Resolution to allow the inverter to remain connected to the CGI was completed in mid-December 2015.

The test program resumed on January 26, 2016. In each case, the drivetrain was operating at 10 rpm and $200 \mathrm{kNm}$ of torque. The primary LVRT faults of interest tested are listed in Table 12; however, additional tests were run with varying voltage drops in a graduated approach. Both symmetrical (three-phase) and asymmetrical (single-phase) faults were tested for each condition. 
Table 12. Symmetrical and Asymmetrical LVRT Tests

\begin{tabular}{cccc}
\hline Date & Disturbance & Reference & $\begin{array}{c}\text { Inverter } \\
\text { Damping }\end{array}$ \\
\hline Jan. 26 & 30 cycles to 90\% of terminal voltage & IEC 61400-21, Table 1, Case VD1 & Disabled \\
Jan. 26 & 30 cycles to 50\% of terminal voltage & IEC 61400-21, Table 1, Case VD2 & Disabled \\
Jan. 26 & 12 cycles to 20\% of terminal voltage & IEC 61400-21, Table 1, Case VD3 & Disabled \\
Jan. 26 & 9 cycles to 15\% of terminal voltage & FERC Order 661-A & Disabled \\
Jan. 26 & 9 cycles to 12\% of terminal voltage & Info. Only & Disabled
\end{tabular}

A portion of the data for the nine-cycle symmetrical LVRT to $12 \%$ of terminal voltage is shown below in Figure 11. At slightly more than 4.5 seconds, the LVRT event is initiated, and the phase voltages reduce to $13 \%$ of nominal. The phase currents increase by up to $135 \%$ for a brief instant, and consequently the drivetrain torques increase by up to $128 \%$.
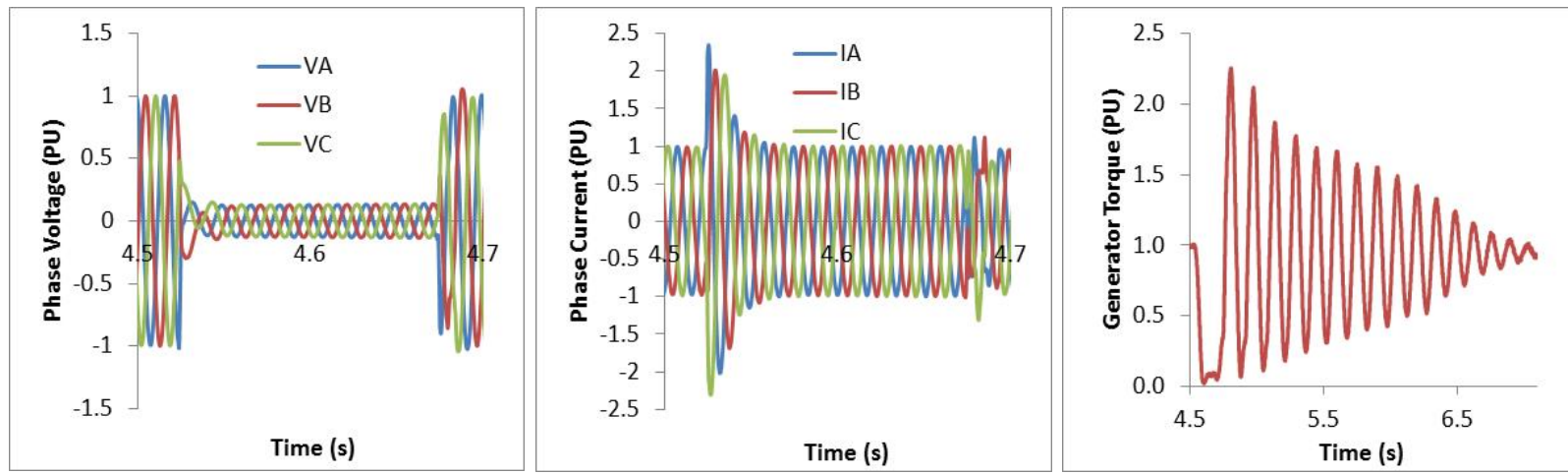

Figure 12. Drivetrain response to a nine-cycle symmetrical LVRT to $12 \%$ of terminal voltage

A less severe 30 -cycle symmetrical LVRT to $50 \%$ of terminal voltage is shown below in Figure 11. The phase voltages reduce to $51 \%$ of nominal. The phase currents increase by up to $60 \%$ for a brief instant, and consequently the drivetrain torques increase by up to $37 \%$. Note that the highest torque value actually occurs when the electrical load returns. That behavior is common among all of the LVRT events. On January 27, additional LVRT events of interest as described in Table 13 were tested based on the previous day's results. Again, in each case the drivetrain was operating at $10 \mathrm{rpm}$ and $200 \mathrm{kNm}$ of torque. 

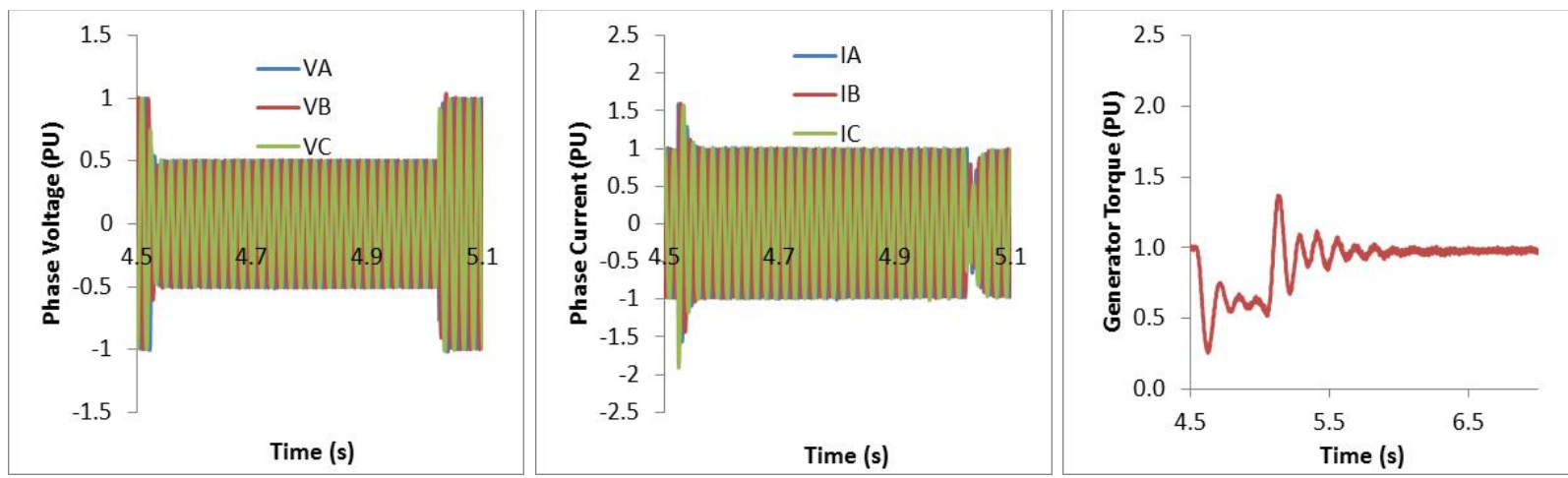

Figure 13. Drivetrain response to a 30 -cycle symmetrical LVRT to $50 \%$ of terminal voltage

Table 13. Additional LVRT Tests

\begin{tabular}{lcc}
\hline Date & Disturbance & $\begin{array}{c}\text { Inverter } \\
\text { Damping }\end{array}$ \\
\hline Jan. 27 & Three-phase faults of 20 ms through 500 -ms durations to $50 \%$ of terminal voltage & Disabled \\
Jan. 27 & Continuous two-phase faults from $70 \%$ to $50 \%$ of terminal voltage & Disabled \\
Jan. 27 & Three-phase faults of nine cycles from $20 \%$ to $5 \%$ of terminal voltage & Disabled \\
\hline
\end{tabular}

The first test sequence was intended to explore the effect of the fault duration on the maximum torque that the drivetrain would experience. There is a relationship between them, as shown in Figure 14. The highest torque spike of $60 \%$ more than nominal is experienced when the fault duration is half of the drivetrain period of oscillation. The magnitude of the highest torque spike is related to the voltage drop; however, the highest torque spike will always occur at half of the drivetrain period of oscillation [17]. As shown in Section 4.1, the drivetrain natural frequency is $6.2 \mathrm{~Hz}$, equating to a period of 161 milliseconds (ms). For an 80-ms LVRT, as shown in Figure 14 , the electrical load returns when the drivetrain is at its maximum unloaded point. In this situation, returning the electrical load has its maximum effect on the drivetrain torque, forcing it to its highest point. As the fault duration increases to longer and longer durations, the torque spike reaches an equilibrium value. In that situation, the initial oscillation has been almost damped out, as shown in Figure 13, so returning the electrical load has only a modest effect. 

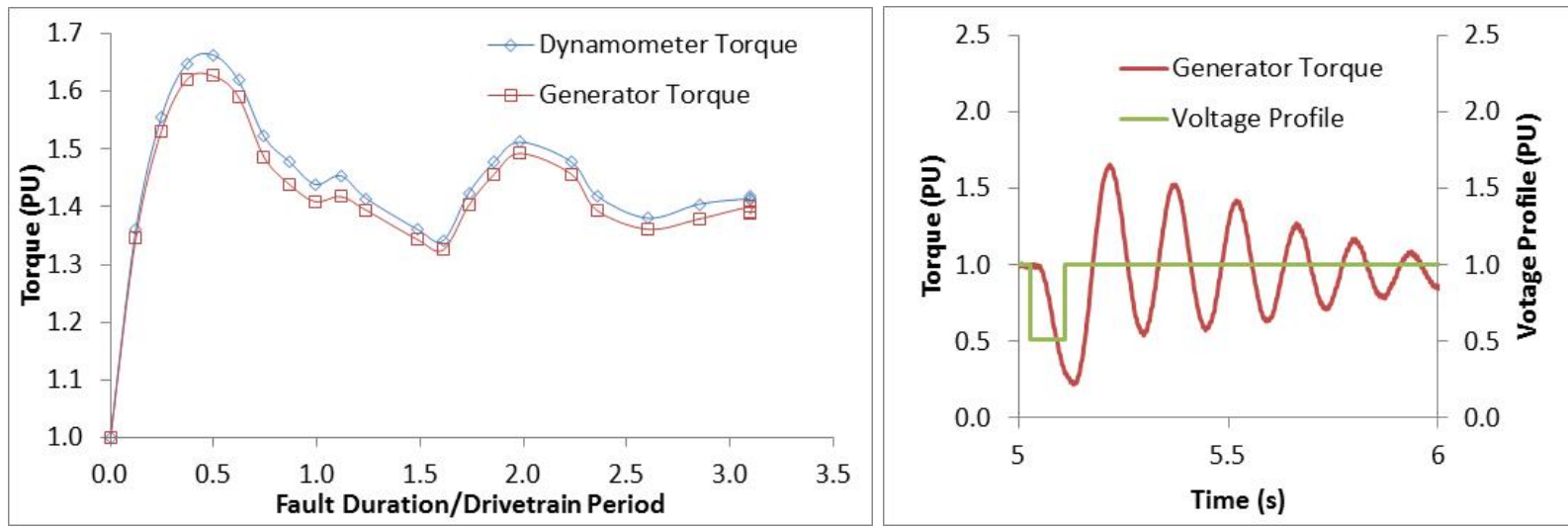

Figure 14. Summary of drivetrain response to LVRT events (left) and worst-case event (right)

On January 27, high-voltage ride-through tests were conducted as listed in Table 14. The drivetrain was typically operating between 10 and $12 \mathrm{rpm}$ and 190 and $210 \mathrm{kNm}$ of torque. Only symmetrical (three-phase) faults were tested, with varying levels of fault duration and magnitude.

Table 14. Symmetrical High-Voltage Ride-Through Tests

\begin{tabular}{llll}
\hline Date & \multicolumn{1}{c}{ Disturbance } & Reference & $\begin{array}{c}\text { Inverter } \\
\text { Damping }\end{array}$ \\
\hline Jan. 27 & 9 cycles to $105 \%$ of terminal voltage & Info. Only & Disabled \\
Jan. 27 & 9 cycles to $110 \%$ of terminal voltage & Info. Only & Disabled \\
Jan. 27 & 9 cycles to $115 \%$ of terminal voltage & Info. Only & Disabled \\
Jan. 27 & 9 cycles to $120 \%$ of terminal voltage & Info. Only & Disabled \\
Jan. 27 & 12 cycles to $120 \%$ of terminal voltage & Info. Only & Disabled \\
Jan. 27 & 12 cycles to $125 \%$ of terminal voltage & Info. Only & Disabled
\end{tabular}

\subsubsection{Frequency Deviation Response}

An algorithm that allows the drivetrain to participate in primary frequency response, modulating output power in response to grid frequency deviations, was developed and simulated. This type of response is required by certain North American transmission system operators, and it is expected to see growing applications as penetrations of intermittent resources such as wind increase. Frequency response tests as identified in Table 15 were conducted. Initial conditions for each test were with the drivetrain operating at $10 \mathrm{rpm}$ on the main shaft and with varying levels of main shaft torque and subsequent real power. At the conclusion of the power converter tests, the contact pattern on all the painted gear teeth was inspected by Romax personnel. 
Table 15. Frequency Response Rests

\begin{tabular}{lccc}
\hline Date & $\begin{array}{c}\text { Dyno } \\
\text { Torque } \\
\mathbf{( k N m )}\end{array}$ & $\begin{array}{c}\text { Real } \\
\text { Power } \\
\mathbf{( k W )}\end{array}$ & Disturbance \\
\hline Jan. 27 & 30 & 0 & Over- and underfrequency transients of $\pm 4 \mathrm{~Hz}$ \\
Jan. 27 & 100 & 70 & Over- and underfrequency transients of $\pm 4 \mathrm{~Hz}$ \\
Jan. 27 & 200 & 170 & Over- and underfrequency transients of $\pm 4 \mathrm{~Hz}$
\end{tabular}

\subsection{Gearbox Journal Bearing Durability Test}

The performance of the planet journal bearings during standstill events was evaluated in this test sequence. The intention is to assess the durability of the journal bearings during motion similar to that which exists in a wind turbine.

\subsubsection{Start-Stop Test}

In this test sequence, the dynamometer was programmed to operate in speed-control mode from standstill up to $10 \mathrm{rpm}$ and back to $0 \mathrm{rpm}$ in 10 seconds followed by 5 seconds of stationary time. This sequence was repeated for 5,000 cycles during the course of 21 hours from November 24 to December 4, 2015. Based on wind turbine operational data, 5,000 start-stop cycles simulated 1 year of field operation. At the conclusion of the start-stop test, Oil Sample \#13 was taken, and the contact pattern on all the painted gear teeth was inspected by Romax personnel. Journal bearing temperatures, International Standards Organization (ISO) oil cleanliness counts, and borescope inspections showed no appreciable signs of accelerated planetary, bearing, or tooth wear. As shown in Figure 15, the ISO oil particle count remained stable at -/13/9 for the entire start-stop test [8]. The shafting connecting the dynamometer gearbox to the NGD was also removed to facilitate the remaining tests.

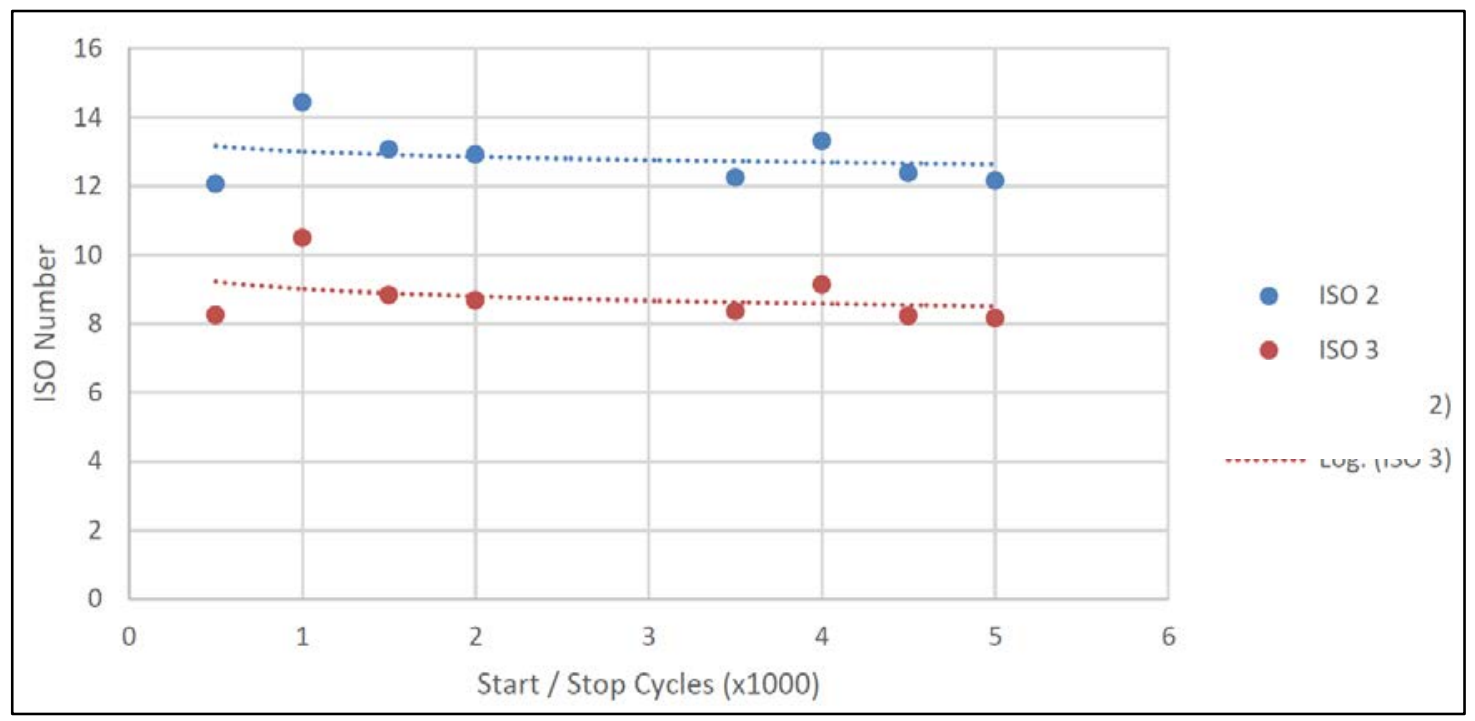

Figure 15. ISO oil cleanliness counts during start-stop testing [8]. Illustration by Romax Technology 


\subsubsection{Locked Rotor Dither Test}

The locked rotor dither test simulated conditions common during turbine maintenance. In this situation, rotation of the output section of the gearbox is largely prevented by a physical lock, yet the rotor and input section of the gearbox can still oscillate by a small amount due to backlash in the gearing and torsional compliance.

The generator rotor was locked for this test by installing a purpose-built locking adapter plate connecting the torque tube to the generator back cover. A hydraulic actuator was installed and connected to the main shaft adapter to input the specified rotor dithering motion in Table 16. The locked rotor dither test commenced on March 11, 2016, and was conducted during a period of 24 total hours concluding on March 16, 2016. The data specified in Table 22 was collected throughout the sequence. At the conclusion of the locked rotor dither test, Oil Sample \#15 was taken, and the main shaft was rotated approximately $45^{\circ}$ in the normal, clockwise direction.

Table 16. Locked Rotor Dither Test

\begin{tabular}{ccccc}
\hline $\begin{array}{c}\text { Main Shaft } \\
\text { Rotation } \\
\text { (deg.) }\end{array}$ & $\begin{array}{c}\text { Frequency Duration Cycles } \\
\text { (Hz) }\end{array}$ & $\begin{array}{c}\text { (hr) } \\
\text { (denerator } \\
\text { Torque } \\
\text { (kNm/\%) }\end{array}$ \\
\hline \pm 0.09 & 1 & 24 & 86,472 & $\pm 3 / \pm 4$ \\
\hline
\end{tabular}

A 10-minute portion of the locked rotor dither test data is shown in Figure 16, which compares the generator torque to the rotation of the main shaft. The hydraulic actuator rotated the main shaft within $\pm 0.09^{\circ}$. The measured generator torque is near zero in the middle part of that rotation because during this period the gear teeth are moving through the backlash. Only on the outside portions of the rotation is any real generator torque measured, corresponding to the gears being in contact and the gear teeth bending slightly. The measured response shown in Figure 16 was monitored throughout the test, and the hydraulic actuator displacement was adjusted periodically to ensure that both the drive and coast side of the gear teeth were contacted by relatively equal amounts.

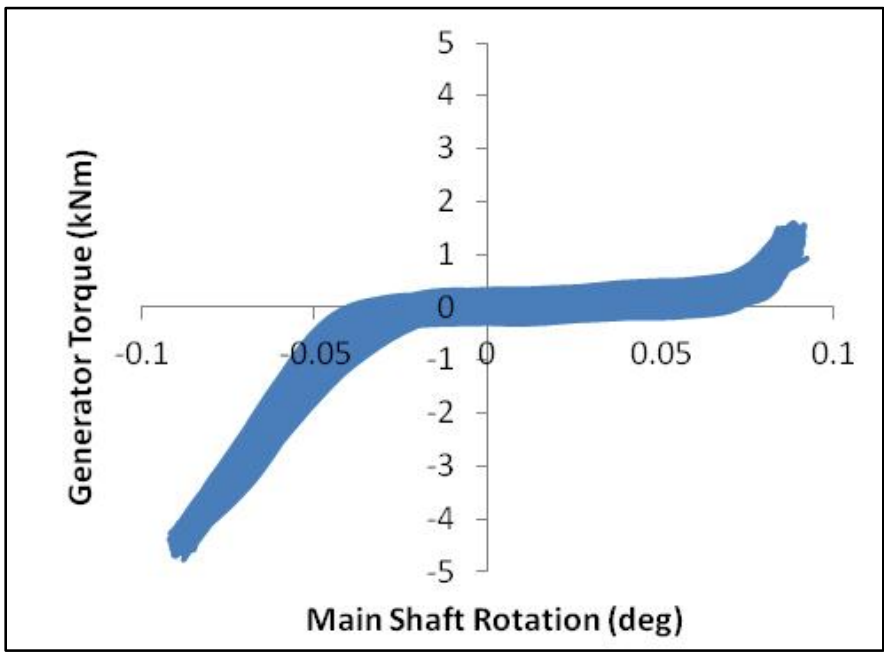

Figure 16. Drivetrain response in locked rotor dither conditions 


\subsubsection{Unlocked Rotor Dither Test}

The unlocked rotor dither test simulated the situation when the rotor is allowed to oscillate back and forth in operation. This could be due to a lack of wind or if the turbine has been placed into idle mode. When shut down, the blades are typically pitched near $90^{\circ}$ with slightly enough lift to keep the drivetrain slowly rotating to prevent fretting or brinelling. Often the rotor fails to continuously rotate in one direction and oscillates back and forth instead.

Initial attempts at this test sequence revealed large variations in the actuator force required to overcome the generator cogging torque, which varies significantly with even minor rotations of the generator. The generator was therefore disconnected from the gearbox by physically disconnecting the torque tube from the generator rotor. The unlocked rotor dither test specified in Table 17 then commenced on March 18 and was conducted during a period of 24 total hours concluding on March 31, 2016. The data specified in Table 22 was collected throughout the sequence. At the conclusion of the unlocked rotor dither test, Oil Sample \#14 was taken.

Table 17. Unlocked Rotor Dither Test

\begin{tabular}{ccccc}
\hline $\begin{array}{c}\text { Main Shaft } \\
\text { Rotation } \\
\text { (deg.) }\end{array}$ & $\begin{array}{c}\text { Frequency } \\
\text { (Hz) }\end{array}$ & $\begin{array}{c}\text { Duration Cycles } \\
\text { (hr) }\end{array}$ & $\begin{array}{c}\text { Generator } \\
\text { Torque } \\
\text { (kNm/\%) }\end{array}$ \\
\hline \pm 5 & $1 / 6$ & 24 & 14,700 & $\pm 1 / \pm 1$ \\
\hline
\end{tabular}

\subsubsection{Oil-Restricted Dither Test}

After reviewing the previously described tests and consulting with Romax Technology, an additional dither test was conducted to determine the journal bearing robustness in dithering conditions with poor or even no oil flow. The setup for both unlocked and oil-restricted dither testing is shown in Figure 17.

The main shaft was again rotated approximately $45^{\circ}$ in the normal, clockwise direction, and the generator remained unlocked. The oil-restricted rotor dither test specified in Table 18 then commenced on April 4 and was conducted during a period of 7.5 total hours. The data specified in Table 22 was collected throughout the sequence, whereas the data specified in Table 20 was collected at the beginning and end of each condition and twice in between. During the portion of the test with zero oil flow, there were no indications in the data of surface contact between the journals and spindles. Actuator forces, oil particle counts, and journal temperatures were stable throughout the test. However, when the oil pump was turned back on for the last 15 minutes of the test and the oil flow rate and planet bearing oil pressure slowly rose, the oil particle count increased from $-/ 10 / 7$ to $-/ 18 / 13$ as particles were flushed out of the gearbox. The oil particle count then slowly declined as the lubrication system began to filter the oil again. At the conclusion of the oil-restricted rotor dither test, Oil Sample \#16 was taken. 
Table 18. Oil-Restricted Rotor Dither Test

\begin{tabular}{ccccccc}
\hline $\begin{array}{c}\text { Main Shaft } \\
\text { Rotation } \\
\text { (deg.) }\end{array}$ & $\begin{array}{c}\text { Frequency } \\
\text { (Hz) }\end{array}$ & $\begin{array}{c}\text { Duration } \\
\text { (hr) }\end{array}$ & $\begin{array}{c}\text { Oil } \\
\text { Flow } \\
\text { (LPM/\%) }\end{array}$ & $\begin{array}{c}\text { Planet Bearing } \\
\text { Oil Pressure } \\
\text { (psi/\%) }\end{array}$ & $\begin{array}{c}\text { Cycles } \\
\text { Generator } \\
\text { Torque } \\
\text { (kNm/\%) }\end{array}$ \\
\hline \pm 0.5 & 2 & $1 / 4$ & $57 / 100 \%$ & $18 / 100 \%$ & 1,800 & $\pm 1 / \pm 1$ \\
\pm 0.5 & 2 & 1 & $16 / 28 \%$ & $4.3 / 25 \%$ & 7,200 & $\pm 1 / \pm 1$ \\
\pm 0.5 & 2 & 6 & $0 / 0 \%$ & $0.3 / 2 \%$ & 43,200 & $\pm 1 / \pm 1$ \\
\pm 0.5 & 2 & $1 / 4$ & 25 to $50 / 44 \%$ to $88 \% 14$ to $17 / 78 \%$ to $94 \%$ & 1,800 & $\pm 1 / \pm 1$ \\
& & & & & &
\end{tabular}

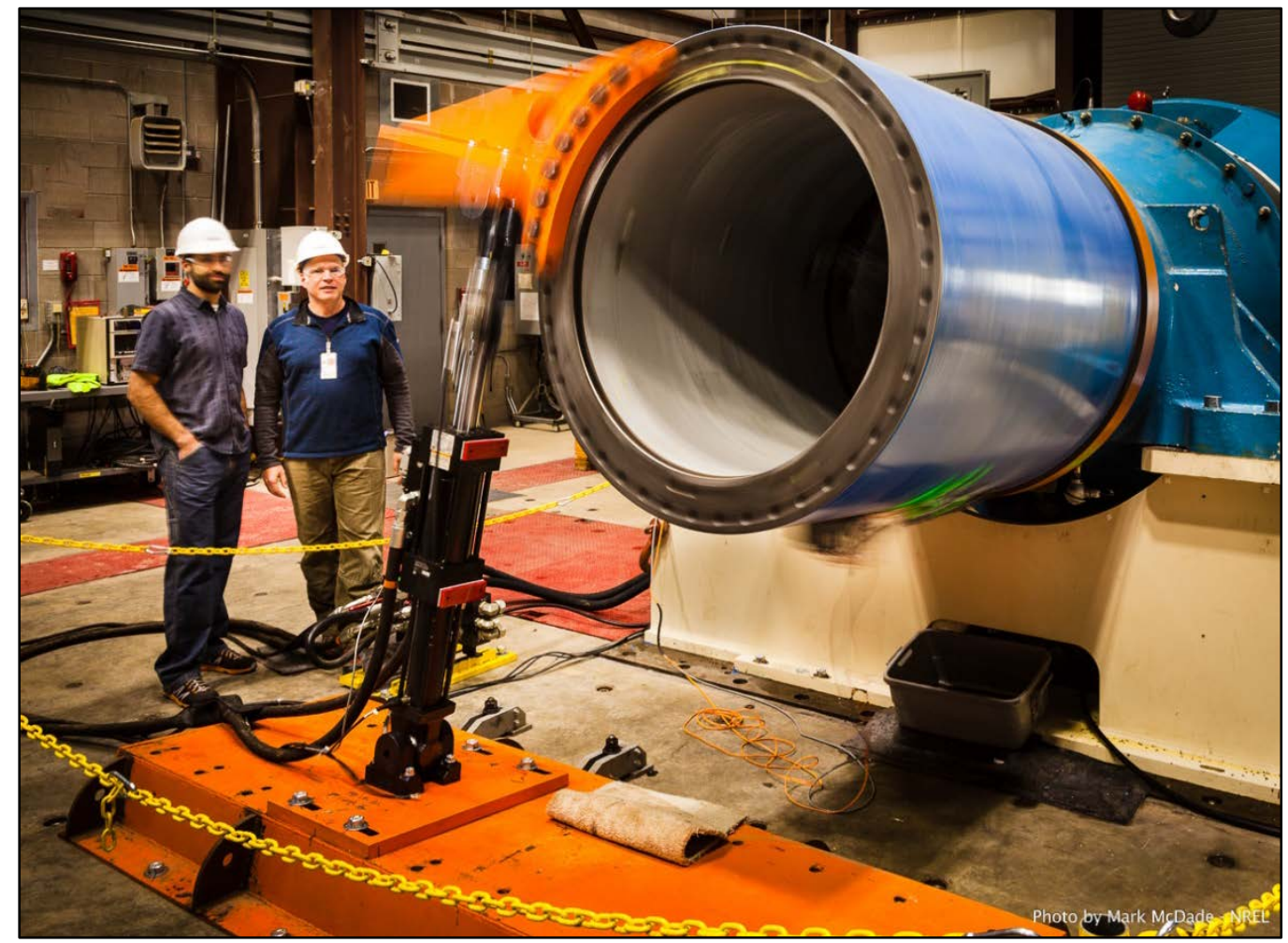

Figure 17. Unlocked and oil-restricted dither testing. Photo by Mark McDade, NREL 36517

\subsection{Post-Test Inspections}

After testing was completed, the generator was disconnected from the rest of the drivetrain on April 26, allowing access to the gearbox. The sun, planet, and ring gear teeth were visually inspected for wear, and the contact pattern on the painted teeth was evaluated. Photographs of the gear condition are shown in Figure 18. 

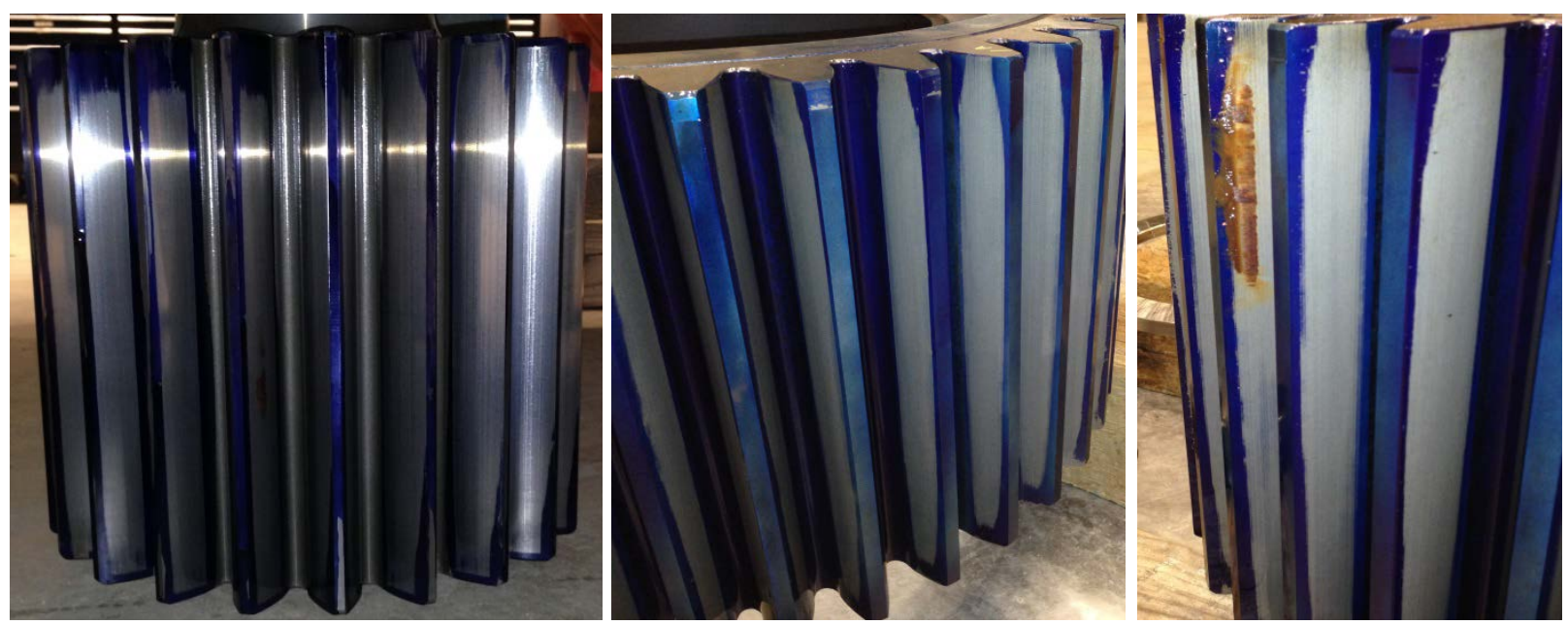

Figure 18. Sun gear (left), normal planet gear (middle), and fretted planet gear (right). Photos by Jonathan Keller, NREL 36730 (left), 36728 (middle), and 36731 (right)

The planets were also removed, and the journal bearings and planet spindle surfaces were visually inspected for wear, as shown in Figure 19. The wear location for the unlocked dither test was approximately $115^{\circ}$ counterclockwise on the journal bearing, when viewed from downwind, from the region of the locked dither test. Similarly, the wear location for the oil-restricted dither test was approximately $115^{\circ}$ counterclockwise on the journal bearing, when viewed from downwind, from the region of the unlocked dither test.

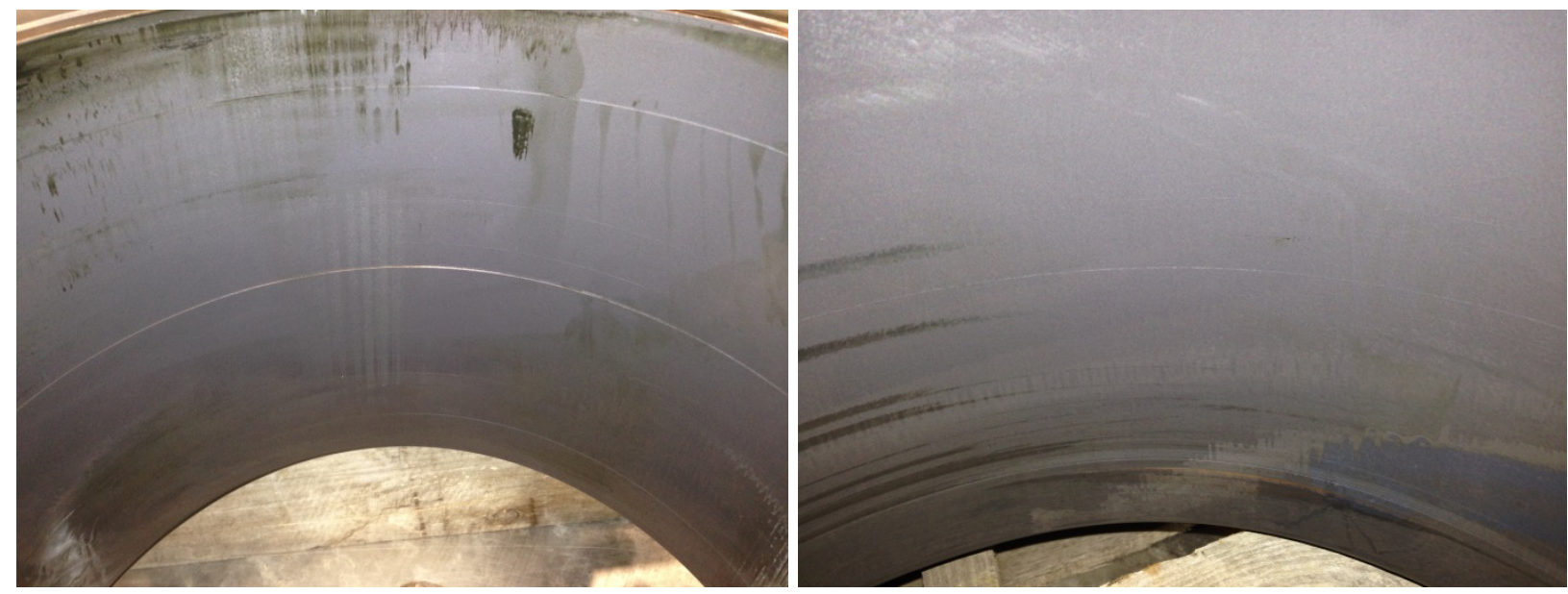

Figure 19. Journal bearing wear patterns. Photos by Jonathan Keller, NREL 36729 (left) and 36732 (right) 


\section{References}

1. Keller, J. 2012. Next Generation Drivetrain Development: DE-FOA-0000439: Phase I Final Reporting for Down-Selection (Technical Report). NREL/MP-5000-54588; DOE/GO102012-3570. National Renewable Energy Laboratory (NREL), Golden, CO (US).

2. Keller, J., W. Erdman, D. Blodgett, D. Grider, and C. Halse. 2014. NREL Prime NextGeneration Drivetrain Midterm Progress Report. (Technical Report) NREL/MP-500061763. National Renewable Energy Laboratory (NREL), Golden, CO (US).

3. Keller, J. and C. Halse. "NREL Next Generation Drivetrain Mechanical Design and Test Plan" (presented at the American Wind Energy Association WINDPOWER Conference and Exhibition, Las Vegas, Nevada, May 5-8, 2014). NREL/PO-5000-61599. Golden, CO: National Renewable Energy Laboratory, 2014. http://www.nrel.gov/docs/fy14osti/61599.pdf.

4. Keller, J. and C. Halse. "Innovative Medium-Speed Drivetrain Design Program and Dynamometer Testing" (presented at the American Wind Energy Association WINDPOWER Conference and Exhibition, Orlando, Florida, May 19-21, 2015). NREL/PR5000-64269. Golden, CO: National Renewable Energy Laboratory, 2015.http://www.nrel.gov/docs/fy15osti/64269.pdf.

5. Keller, J., W. Erdman, D. Blodgett, C. Halse, and J. Ukonsaari. NREL Next Generation Drivetrain: Dynamometer Test Plan. Golden, CO: NREL. National Renewable Energy Laboratory, 2015.

6. Keller, J., W. Erdman, D. Blodgett, C. Halse, and D. Grider. 2015. "Next Generation Drivetrain Development and Test Program" (presented at the Drivetrain Conference for Wind Turbines, Bremen, Germany, November 30, 2015). NREL/PR-5000-65497. Golden, CO: National Renewable Energy Laboratory. http://www.nrel.gov/docs/fy16osti/65497.pdf.

7. Blodgett, D. NREL Next Generation Drivetrain Test Report: Deviations. (Technical Report) 10004954-1. Oslo, Norway: DNV GL, February 2016.

8. Halse, C. Next Generation Drivetrain Gearbox Assembly and Test Report. (Technical Report) 1552-DC-052. Nottingham, United Kingdom: Romax Technology, March 2016.

9. Walford, C., L. Lybarger, T. Lettenmaier, and D. Roberts. 2012. Medium-Speed Drivetrain Test Report: September 1, 2002-December 30, 2007. (Technical Report) NREL/SR-500051175. Golden, CO: National Renewable Energy Laboratory. http://www.nrel.gov/docs/fy12osti/51175.pdf.

10. Halse, C. 2014. Test and Instrumentation Plan. (Technical Report) 1552-DC-004. Nottingham, United Kingdom: Romax Technology.

11. National Renewable Energy Laboratory. "Dynamometer Testing: National Wind Technology Center.” (Fact Sheet) NREL/FS-5000-45649. Golden, CO: 2010. 
12. National Renewable Energy Laboratory. "Controllable Grid Interface: National Wind Technology Center.” (Fact Sheet) NREL/FS-5000-53800. Golden, CO: 2012.

13. Halse, C. Gearbox Interface Specification. (Technical Report) 1552-DC-003. Nottingham, United Kingdom: Romax Technology, 2014.

14. Blodgett, D., M. Behnke, and W. Erdman. Power Converter Control Algorithm Design and Simulation for the NREL Next Generation Drivetrain. (Technical Report). Oslo, Norway: DNV KEMA Renewables, 2014.

15. Federal Energy Regulatory Commission. Order 661-A: Interconnection for Wind Energy. December 12, 2005.

16. International Electrotechnical Commission. IEC 61400-21: Edition 2-Wind Turbines - Part 21: Measurement and Assessment of Power Quality Characteristics of Grid Connected Wind Turbines.

17. Huhn, H., M. Hopp, and C. Jauch. "Additional Design Criteria for Wind Turbines: Excitation to Mechanical Vibrations from the Power System" (presented at Conference 6, VDIFachtagung Schwingungen von Windenergieanlagen, June 2015). DOI: 10.13140/RG.2.1.3870.6409. 


\section{Appendix}

RING GEAR LOAD DISTRIBUTION 1552-LY-003-A

NREL NEXTGEN 29APR2015

RING GEAR FACEWIDTH $=\quad 310 \mathrm{MM}$

PLANET GEAR FACEWIDTH $=300 \mathrm{MM}$ SPACING BETWEEN GAUGES $=40 \mathrm{MM}$

AXIAL DISTANCE FROM UW TOOTH END:

GAUGE $A=15 \mathrm{MM}$

GAUGE B $=55 \mathrm{MM}$

GAUGE $C=95 \mathrm{MM}$

GAUGE D $=135 \mathrm{MM}$

GAUGE $E=175 \mathrm{MM}$

GAUGE $F=215 \mathrm{MM}$

GAUGE $G=255 \mathrm{MM}$

GAUGE H $=295 \mathrm{MM}$

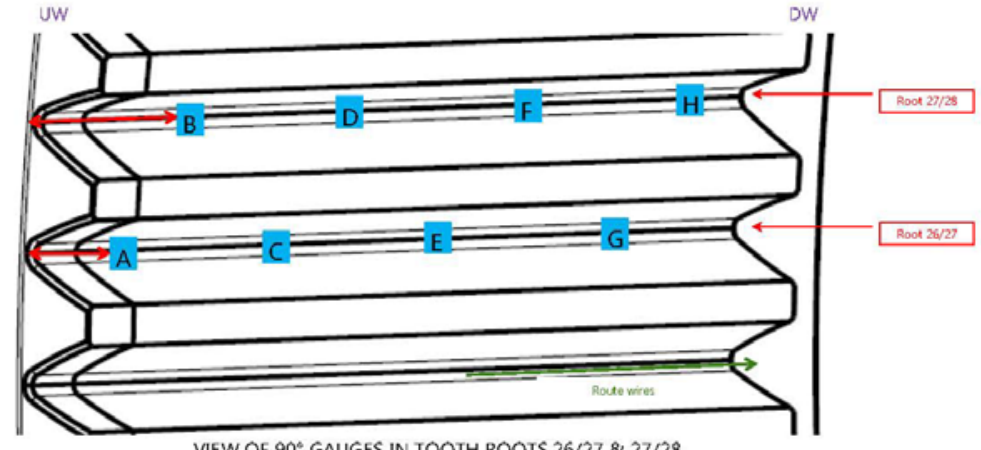

VIEW OF $90^{\circ}$ GAUGES IN TOOTH ROOTS $26 / 27 \& 27 / 28$

[SAME LAYOUT IN OTHER LOCATIONS]

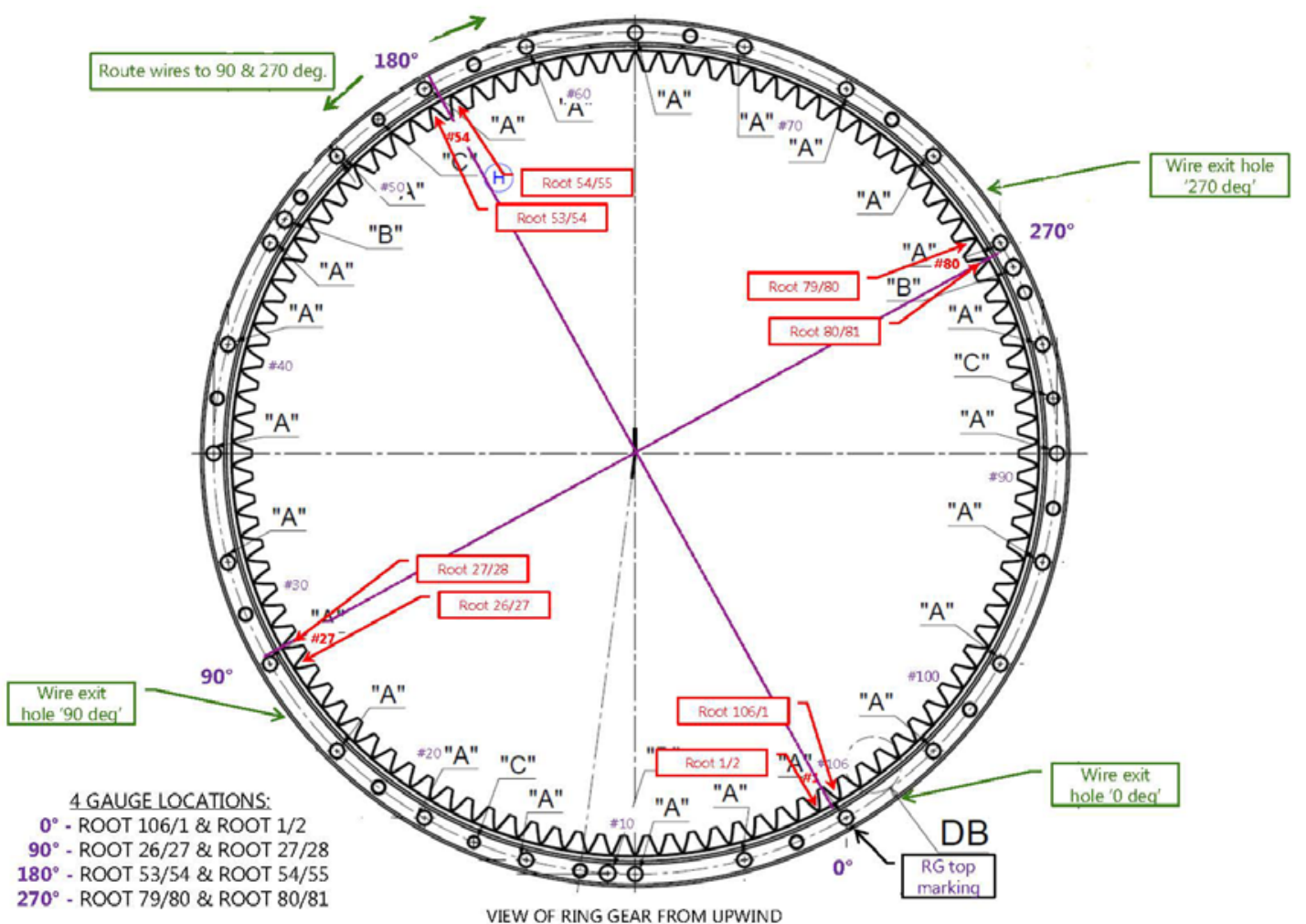

$270^{\circ}$ - ROOT 79/80 \& ROOT 80/81

VIEW OF RING GEAR FROM UPWIND

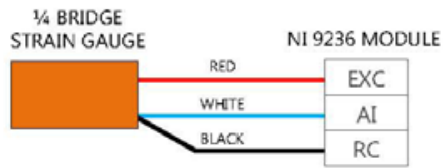

NOTES:

1. LEADS ARE 3 CONDUCTOR 26AWG SHIELDED VINYL (326-DSV).

2. GAUGES INSTALLED WEEK OF 26 JAN 2015.

\begin{tabular}{|l|l|}
\hline SIGNAL COUNT & 32 CHANNELS (8 GAUGES PER LOCATION) \\
\hline CHANNELS 1-8 & RING_0_DEG_A -> RING_0_DEG_H \\
\hline CHANNELS 9-16 & RING_90_DEG_A -> RING_90_DEG_H \\
\hline CHANNELS 17-24 & RING_180_DEG_A -> RING_180_DEG_H \\
\hline CHANNELS 25-32 & RING_270_DEG_A -> RING_270_DEG_H \\
\hline SENSOR & EA-06-031EC-350 \\
\hline MOUNTING & CYANOACRYLATE (M-BOND 200) \\
\hline COATING & RTV (M-COAT C \& 3145) \\
\hline SIGNAL COND & NI 9236 QUARTER BRIDGE MODULE \\
\hline
\end{tabular}

Figure 20. Ring gear tooth instrumentation. Illustration by Romax Technology 
DRIVETRAIN VIBRATION

1552-LY-005-A

NREL NEXTGEN 27APR2015
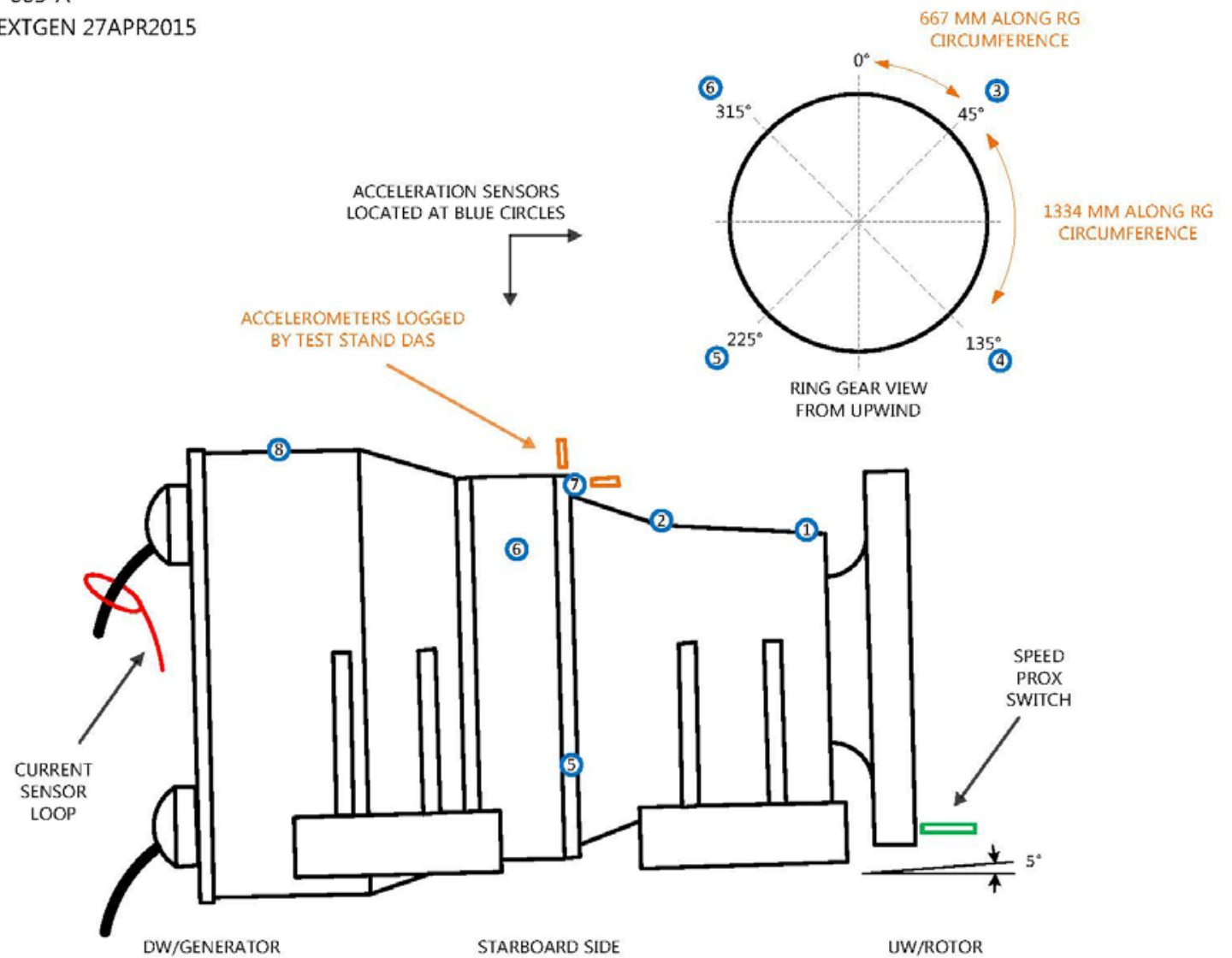

\begin{tabular}{|l|l|l|}
\hline \multicolumn{1}{|c|}{ SENSOR: } & \multicolumn{1}{c|}{ LOCATION: } & \multicolumn{1}{c|}{ NOTES: } \\
\hline ACCEL \# 1 & UW MAIN BEARING (0 DEG) & \\
\hline ACCEL \# 2 & DW MAIN BEARING (0 DEG) & \\
\hline ACCEL \# 3 & PLANETARY 45 DEG & ON FRONT CASING FLANGE \\
\hline ACCEL \# 4 & RING GEAR 135 DEG & ON RING OD MID WIDTH \\
\hline ACCEL \# 5 & PLANETARY 225 DEG & ON FRONT CASING FLANGE \\
\hline ACCEL \# 6 & RING GEAR 315 DEG & ON RING OD MID WIDTH \\
\hline ACCEL \# 7 & PLANETARY AXIAL (0 DEG) & MOUNTED AXIALLY ON FLANGE \\
\hline ACCEL \# 8 & GENERATOR (0 DEG) & \\
\hline SPEED PROX & LSS HUB BOLTS & TBD \# BOLTS PER REV \\
\hline CURRENT & GENERATOR CABLE(S) & \\
\hline
\end{tabular}

NOTES:

1. Accelerometers \#3 and \#4 on PORTSIDE. (not pictured)

2. Sampling set to trigger on speed and elapsed time.

3. The generator has 4 quadrants with 3 phases each.

\begin{tabular}{|l|l|}
\hline SENSOR & ACCELEROMETER \\
\hline SAMPLE RATE & $25600 \mathrm{HZ}$ \\
\hline MOUNTING & MAGNETIC BASES \\
\hline SENSITIVTY & $100 \mathrm{mV} / \mathrm{g}$ \\
\hline FREQ RANGE & $0.5-10 \mathrm{kHz}$ \\
\hline SAMPLE LENGTH & 60 SEC \\
\hline DAS & ROMAX PVS NI CRIO \\
\hline
\end{tabular}

Figure 21. Gearbox vibration instrumentation. Illustration by Romax Technology 
PLANET PIN BENDING

1552-LY-001-A

NREL NEXTGEN 1MAY2015

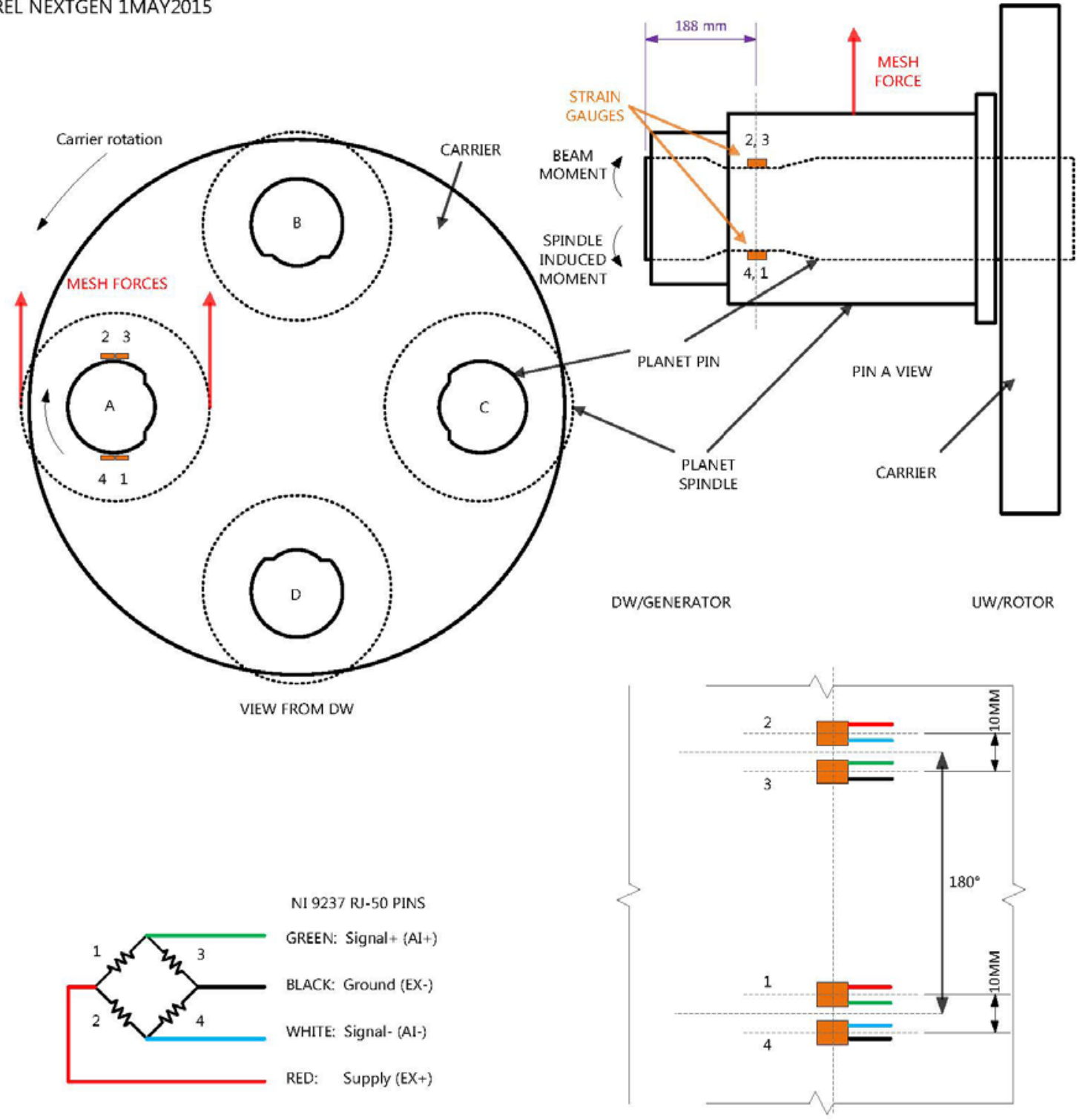

PIN SURFACE ROLLED OUT FLAT

NOTES:

1. SIGN CONVENTION: NEGATIVE STRAIN WHEN SPINDLE INDUCED MOMENT IS GREATER THAN THE MESH FORCE BEAM MOMENT.

2. PIN A GAUGE \#2 BONDED WITH M-BOND 200, GLUE LINE EXPECTED TO

DEGRADE SOONER (6-12 MONTHS) THAN THOSE WITH AE-10.

3. BRIDGE COMPLETION WITH SOLDER TERMINALS, LEADS ARE 4

CONDUCTOR 26AWG SHIELDED VINYL (426-BSV)

4. REFER TO: 1552-GS-003 PLANET GEAR PIN \&

1552-LY-006 PLANET PIN CALIBRATION

5. GAUGES INSTALLED WEEK OF 8 DEC 2014.

\begin{tabular}{|l|l|}
\hline SIGNAL & PIN_A_BENDING \\
\hline & PIN_B_BENDING \\
\hline & PIN_C_BENDING \\
\hline & PIN_D_BENDING \\
\hline SENSOR & CEA-06-125UN-350 \\
\hline MOUNTING & AE-10 EPOXY \\
\hline SIGNAL COND & FULL BRIDGE STRAIN NI 9237 \\
\hline COATING & AE-10 \& RTV \\
\hline
\end{tabular}

Figure 22. Flex pin instrumentation. Illustration by Romax Technology 
PLANET BEARING TEMPERATURE

1552-LY-002-A

NREL NEXTGEN 1MAY2015
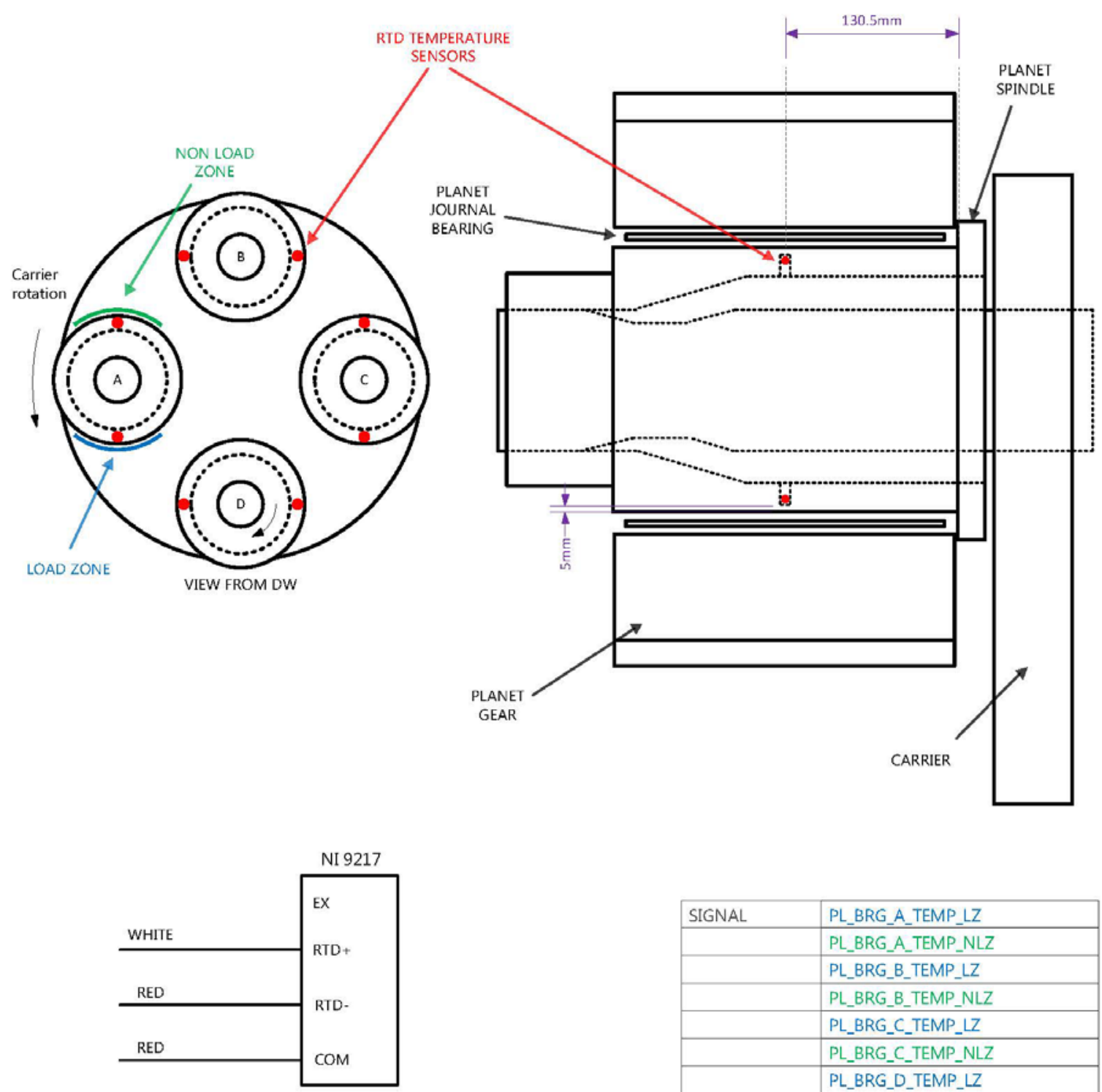

NOTES:

1. GAUGES INSTALLED WEEK OF 8 DEC 2014.

\begin{tabular}{|l|l|}
\hline SIGNAL & PL_BRG_A_TEMP_LZ \\
\hline & PL_BRG_A_TEMP_NLZ \\
\hline & PL_BRG_B_TEMP_LZ \\
\hline & PL_BRG_B_TEMP_NLZ \\
\hline & PL_BRG_C_TEMP_LZ \\
\hline & PL_BRG_C_TEMP_NLZ \\
\hline & PL_BRG___TEMP_LZ \\
\hline & PL_BRG_D_TEMP_NLZ \\
\hline SENSOR & 3 WIRE PT100 RTD \\
\hline & AT $0^{\circ}: 100 \Omega+$ /-0.06 $\Omega$, CLASS A \\
\hline & OMEGA RTD-2-F3105-36-T \\
\hline MOUNTING & OMEGA CERAMIC CEMENT \\
\hline SIGNAL COND & RTD AI MODULE (NI 9217) \\
\hline CABLE & 3 CONDUCTOR 24AWG \\
\hline & (NOT SHIELDED) \\
\hline
\end{tabular}

Figure 23. Journal bearing temperature instrumentation. Illustration by Romax Technology 
PLANET BEARING A OIL TEMPERATURE \& PRESSURE

1552-LY-004-A

NREL NEXTGEN 5MAY2015

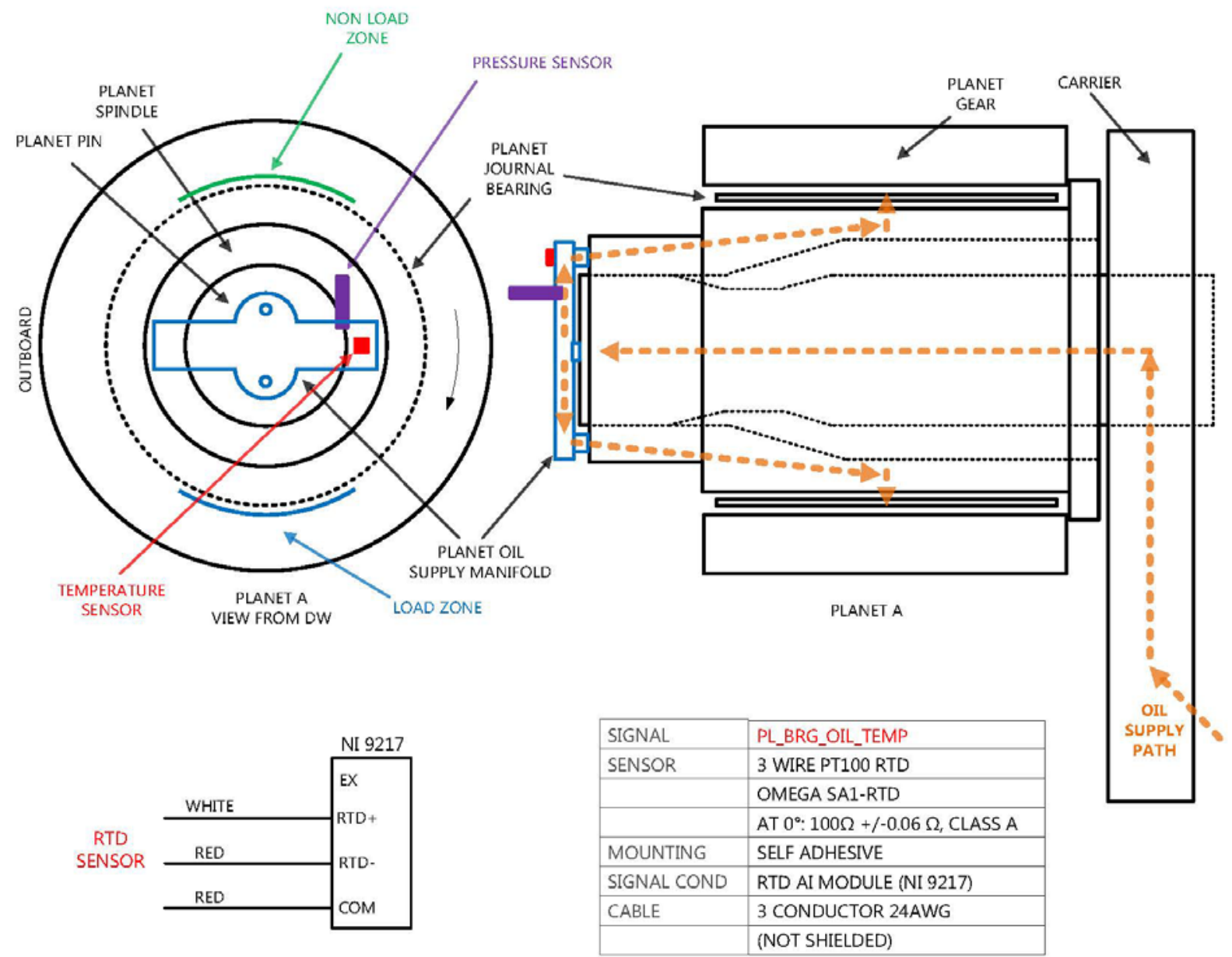

NOTES:

1. PLANET A IS THE ONLY ONE OF THE 4 PLANETS WITH OIL TEMP AND PRESSURE SENSORS.

2. GAUGES INSTALLED WEEK OF 9 MAR 2015

3. PLANET OIL MANIFOLD IS MACHINED ALUMINUM.

4. OIL PRESSURE CALIBRATION CURVE 0-5VDC OUTPUT.

5. GROUND SHIELD ON DAS SIDE.

PX319 SENSOR

MINI DIN CONNECTOR

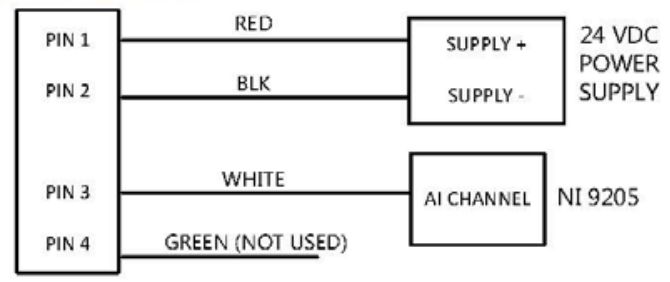

\begin{tabular}{|l|l|}
\hline SIGNAL & PL_BRG_OIL_PRESS \\
\hline SENSOR & OMEGA PX319-100G5V \\
\hline MOUNTING & $1{ }^{\prime \prime}$ NPT \\
\hline SIGNAL COND & AI MODULE (NI 9205) \\
\hline SUPPLY & $9-30$ VDC $(<10 \mathrm{~mA})$ \\
\hline SIGNAL & $0-5$ VDC \\
\hline CONNECTOR & MINI DIN 4 PIN \\
\hline CABLE & 4 CONDUCTOR 24AWG \\
\hline & SHIELDED \\
\hline
\end{tabular}

Figure 24. Oil supply temperature and pressure instrumentation. Illustration by Romax Technology 
Table 19. Performance Data Elements (10-Hz Continuous)

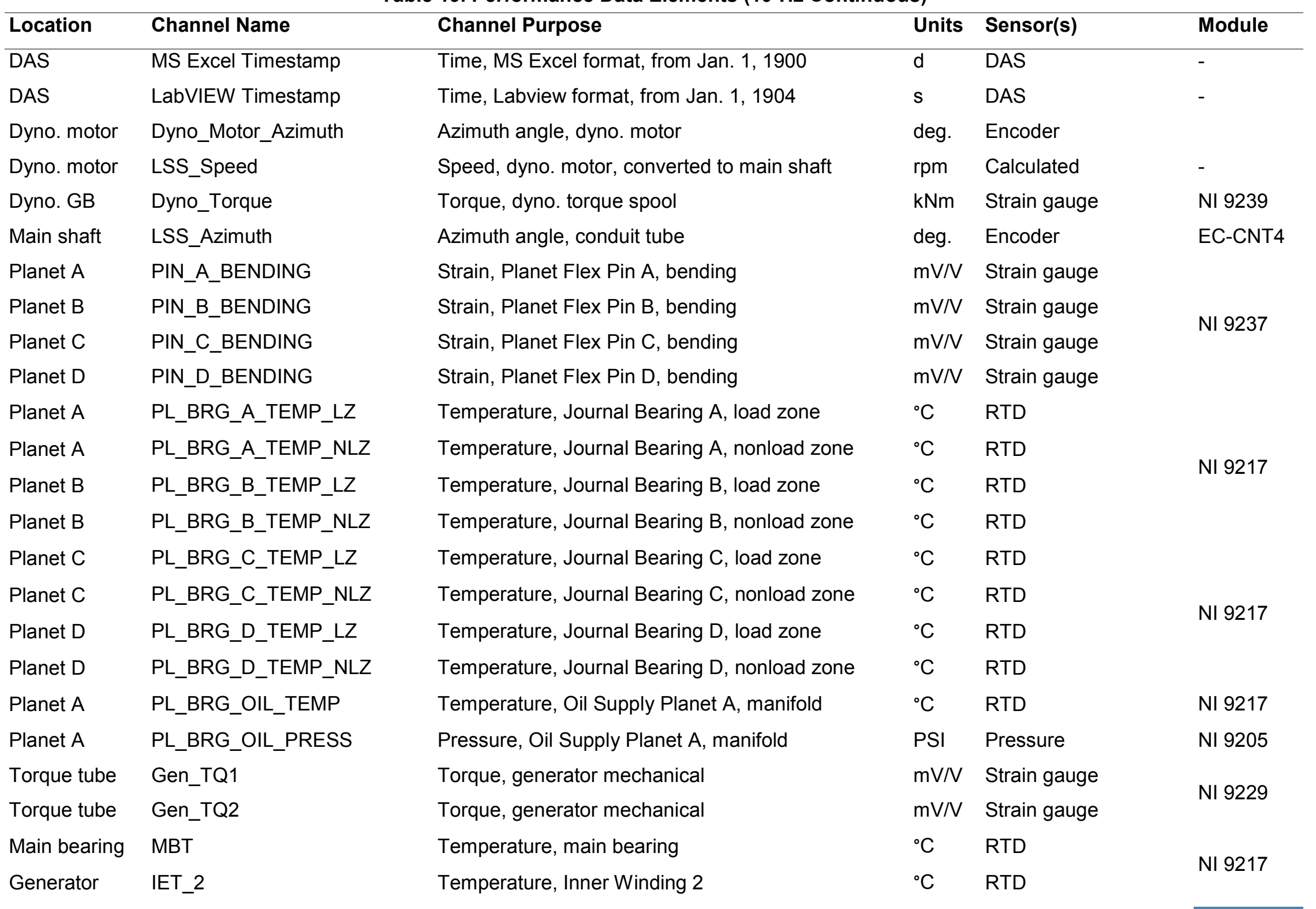




\begin{tabular}{|c|c|c|c|c|c|}
\hline Location & Channel Name & Channel Purpose & Units & Sensor(s) & Module \\
\hline Generator & IET_9 & Temperature, Inner Winding 9 & ${ }^{\circ} \mathrm{C}$ & RTD & \multirow{7}{*}{ NI 9217} \\
\hline Main bearing & BLT & Temperature, lubrication oil at main bearing & ${ }^{\circ} \mathrm{C}$ & RTD & \\
\hline Generator & IET_11 & Temperature, Inner Winding 11 & ${ }^{\circ} \mathrm{C}$ & RTD & \\
\hline Generator & OET_2 & Temperature, Outer Winding 2 & ${ }^{\circ} \mathrm{C}$ & RTD & \\
\hline Generator & OET_9 & Temperature, Outer Winding 9 & ${ }^{\circ} \mathrm{C}$ & RTD & \\
\hline Generator & OET_11 & Temperature, Outer Winding 11 & ${ }^{\circ} \mathrm{C}$ & RTD & \\
\hline Generator & OET_4 & Temperature, Winding 4A & ${ }^{\circ} \mathrm{C}$ & RTD & \\
\hline Generator & 4B & Temperature, Winding 4B & ${ }^{\circ} \mathrm{C}$ & RTD & \multirow{2}{*}{ NI 9217} \\
\hline Generator & $4 \mathrm{C}$ & Temperature, Winding 4C & ${ }^{\circ} \mathrm{C}$ & RTD & \\
\hline Generator & IET_4 & Temperature, Winding 4D & ${ }^{\circ} \mathrm{C}$ & RTD & \multirow{3}{*}{ NI 9235} \\
\hline Transformer & $\mathrm{kW}$ & Power, real & $\mathrm{kW}$ & Transformer & \\
\hline Transformer & kVAR & Power, reactive & kVAR & Transformer & \\
\hline Lube system & ISO_OIL_CLEAN & Oil cleanliness, raw signal & - & Hydac CSM 1220 & NI 9239 \\
\hline Lube system & ISO_1 & Oil cleanliness, Bin 1 & - & Hydac CSM 1220 & - \\
\hline Lube system & ISO_2 & Oil cleanliness, Bin 2 & - & Hydac CSM 1220 & - \\
\hline Lube system & ISO_3 & Oil cleanliness, Bin 3 & - & Hydac CSM 1220 & - \\
\hline Lube system & Lube_Fan_Speed & Speed, lubrication cooler fan & rpm & Fan speed & \\
\hline Lube system & Lube_Flow_Calc & Flow rate, calculated from lubrication pump & LPM & - & - \\
\hline Lube system & Lube_Manifold_Temp & Temperature, oil at distribution manifold & ${ }^{\circ} \mathrm{C}$ & RTD & \multirow{4}{*}{ NI 9217} \\
\hline Lube system & Lube_Manifold_Pressure & Pressure, oil at distribution manifold & PSI & Pressure & \\
\hline Lube system & Lube_Flow_Meter & Flow rate, measured after lubrication pump & LPM & Flow meter & \\
\hline Lube system & Lube_Return_Temp & Temperature, oil from gearbox sump & ${ }^{\circ} \mathrm{C}$ & RTD & \\
\hline
\end{tabular}


Table 20. "Burst" Data Elements (2 kHz for 60-Second Duration)

\begin{tabular}{|c|c|c|c|c|c|}
\hline Location & Channel Name & Channel Purpose & Units & Sensor(s) & Module \\
\hline DAS & MS Excel Timestamp & Time, MS Excel format, from Jan. 1, 1900 & days & DAS & - \\
\hline DAS & LabVIEW Timestamp & Time, Labview format, from Jan. 1, 1904 & $S$ & DAS & - \\
\hline Dyno. motor & Dyno_Motor_Azimuth & Azimuth angle, dyno. motor & deg. & Encoder & \\
\hline Dyno. motor & LSS_Speed & Speed, dyno. motor, converted to main shaft & rpm & Calculated & - \\
\hline Dyno. motor & Dyno_Motor_Torque & Torque, dyno. motor & $\mathrm{kNm}$ & Calculated & - \\
\hline Dyno. motor & Damping_Command & Torque compensation & $\mathrm{kNm}$ & Calculated & - \\
\hline Dyno. motor & Start_StopCycleCount & Counter, start-stop cycles & - & Calculated & - \\
\hline Dyno GB & Dyno_Torque & Torque, dyno. gearbox torque spool & $\mathrm{kNm}$ & Strain gauge & NI 9239 \\
\hline Main shaft & LSS_Azimuth & Azimuth angle, conduit tube & deg. & Encoder & EC-CNT4 \\
\hline Ring gear & RING_0_DEG_A & Strain, ring gear, $0^{\circ}$ location & $\mathrm{mV} / \mathrm{V}$ & Strain gauge & \multirow{5}{*}{ NI 9236} \\
\hline Ring gear & RING_0_DEG_B & Strain, ring gear, $0^{\circ}$ location & $\mathrm{mV} / \mathrm{V}$ & Strain gauge & \\
\hline Ring gear & RING_0_DEG_C & Strain, ring gear, $0^{\circ}$ location & $\mathrm{mV} / \mathrm{V}$ & Strain gauge & \\
\hline Ring gear & RING_0_DEG_D & Strain, ring gear, $0^{\circ}$ location & $\mathrm{mV} / \mathrm{V}$ & Strain gauge & \\
\hline Ring gear & RING_0_DEG_E & Strain, ring gear, $0^{\circ}$ location & $\mathrm{mV} / \mathrm{V}$ & Strain gauge & \\
\hline Ring gear & RING_0_DEG_F & Strain, ring gear, $0^{\circ}$ location & $\mathrm{mV} / \mathrm{V}$ & Strain gauge & \multirow{2}{*}{ NI 9236} \\
\hline Ring gear & RING_0_DEG_G & Strain, ring gear, $0^{\circ}$ location & $\mathrm{mV} / \mathrm{V}$ & Strain gauge & \\
\hline Ring gear & RING_0_DEG_H & Strain, ring gear, $0^{\circ}$ location & $\mathrm{mV} / \mathrm{V}$ & Strain gauge & \\
\hline Ring gear & RING_90_DEG_A & Strain, ring gear, $90^{\circ}$ location & $\mathrm{mV} / \mathrm{V}$ & Strain gauge & \multirow{5}{*}{ NI 9236} \\
\hline Ring gear & RING_90_DEG_B & Strain, ring gear, $90^{\circ}$ location & $\mathrm{mV} / \mathrm{V}$ & Strain gauge & \\
\hline Ring gear & RING_90_DEG_C & Strain, ring gear, $90^{\circ}$ location & $\mathrm{mV} / \mathrm{V}$ & Strain gauge & \\
\hline Ring gear & RING_90_DEG_D & Strain, ring gear, $90^{\circ}$ location & $\mathrm{mV} / \mathrm{V}$ & Strain gauge & \\
\hline Ring gear & RING_90_DEG_E & Strain, ring gear, $90^{\circ}$ location & $\mathrm{mV} / \mathrm{V}$ & Strain gauge & \\
\hline Ring gear & RING_90_DEG_F & Strain, ring gear, $90^{\circ}$ location & $\mathrm{mV} / \mathrm{V}$ & Strain gauge & NI 9236 \\
\hline Ring gear & RING_90_DEG_G & Strain, ring gear, $90^{\circ}$ location & $\mathrm{mV} / \mathrm{V}$ & Strain gauge & \\
\hline
\end{tabular}




\begin{tabular}{|c|c|c|c|c|c|}
\hline Location & Channel Name & Channel Purpose & Units & Sensor(s) & Module \\
\hline Ring gear & RING_90_DEG_H & Strain, ring gear, $90^{\circ}$ location & $\mathrm{mV} / \mathrm{V}$ & Strain gauge & \multirow{5}{*}{ NI 9236} \\
\hline Ring gear & RING_180_DEG_A & Strain, ring gear, $180^{\circ}$ location & $\mathrm{mV} / \mathrm{V}$ & Strain gauge & \\
\hline Ring gear & RING_180_DEG_B & Strain, ring gear, $180^{\circ}$ location & $\mathrm{mV} / \mathrm{V}$ & Strain gauge & \\
\hline Ring gear & RING_180_DEG_C & Strain, ring gear, $180^{\circ}$ location & $\mathrm{mV} / \mathrm{V}$ & Strain gauge & \\
\hline Ring gear & RING_180_DEG_D & Strain, ring gear, $180^{\circ}$ location & $\mathrm{mV} / \mathrm{V}$ & Strain gauge & \\
\hline Ring gear & RING_180_DEG_E & Strain, ring gear, $180^{\circ}$ location & $\mathrm{mV} / \mathrm{V}$ & Strain gauge & \multirow{4}{*}{ NI 9236} \\
\hline Ring gear & RING_180_DEG_F & Strain, ring gear, $180^{\circ}$ location & $\mathrm{mV} / \mathrm{V}$ & Strain gauge & \\
\hline Ring gear & RING_180_DEG_G & Strain, ring gear, $180^{\circ}$ location & $\mathrm{mV} / \mathrm{V}$ & Strain gauge & \\
\hline Ring gear & RING_180_DEG_H & Strain, ring gear, $180^{\circ}$ location & $\mathrm{mV} / \mathrm{V}$ & Strain gauge & \\
\hline Ring gear & RING_270_DEG_A & Strain, ring gear, $270^{\circ}$ location & $\mathrm{mV} / \mathrm{V}$ & Strain gauge & \multirow{4}{*}{ NI 9236} \\
\hline Ring gear & RING_270_DEG_B & Strain, ring gear, $270^{\circ}$ location & $\mathrm{mV} / \mathrm{V}$ & Strain gauge & \\
\hline Ring gear & RING_270_DEG_C & Strain, ring gear, $270^{\circ}$ location & $\mathrm{mV} / \mathrm{V}$ & Strain gauge & \\
\hline Ring gear & RING_270_DEG_D & Strain, ring gear, $270^{\circ}$ location & $\mathrm{mV} / \mathrm{V}$ & Strain gauge & \\
\hline Ring gear & RING_270_DEG_E & Strain, ring gear, $270^{\circ}$ location & $\mathrm{mV} / \mathrm{V}$ & Strain gauge & \multirow{4}{*}{ NI 9236} \\
\hline Ring gear & RING_270_DEG_F & Strain, ring gear, $270^{\circ}$ location & $\mathrm{mV} / \mathrm{V}$ & Strain gauge & \\
\hline Ring gear & RING_270_DEG_G & Strain, ring gear, $270^{\circ}$ location & $\mathrm{mV} / \mathrm{V}$ & Strain gauge & \\
\hline Ring gear & RING_270_DEG_H & Strain, ring gear, $270^{\circ}$ location & $\mathrm{mV} / \mathrm{V}$ & Strain gauge & \\
\hline Ring gear & ACCEL_RADIAL & Acceleration, gearbox housing, radial & $\mathrm{mV} / \mathrm{g}$ & Accelerometer & \multirow{2}{*}{ NI 9232} \\
\hline Ring gear & ACCEL_AXIAL & Acceleration, gearbox housing, axial & $\mathrm{mV} / \mathrm{g}$ & Accelerometer & \\
\hline Planet A & PIN_A_BENDING & Strain, Planet Flex Pin A, bending & $\mathrm{mV} / \mathrm{V}$ & Strain gauge & \multirow{4}{*}{ NI 9237} \\
\hline Planet B & PIN_B_BENDING & Strain, Planet Flex Pin B, bending & $\mathrm{mV} / \mathrm{V}$ & Strain gauge & \\
\hline Planet C & PIN_C_BENDING & Strain, Planet Flex Pin C, bending & $\mathrm{mV} / \mathrm{V}$ & Strain gauge & \\
\hline Planet D & PIN_D_BENDING & Strain, Planet Flex Pin D, bending & $\mathrm{mV} / \mathrm{V}$ & Strain gauge & \\
\hline Torque tube & Gen_TQ1 & Torque, generator mechanical & $\mathrm{mV} / \mathrm{V}$ & Strain gauge & \multirow{2}{*}{ NI 9229} \\
\hline Torque tube & Gen_TQ2 & Torque, generator mechanical & $\mathrm{mV} / \mathrm{V}$ & Strain gauge & \\
\hline
\end{tabular}




\begin{tabular}{lllll}
\hline Location & Channel Name & Channel Purpose & Units & Sensor(s) \\
\hline Inverter & VDC_1 & DC bus voltage & V & Voltage probe \\
Inverter & PhaseA_V & AC voltage, inverter, Phase A & V & Voltage probe \\
Inverter & PhaseB_V & AC voltage, inverter, Phase B & V & Voltage probe \\
Inverter & PhaseC_V & AC voltage, inverter, Phase C & V & Voltage probe \\
Inverter & PhaseA_I & AC current, inverter, Phase A & A & Current probe \\
Inverter & PhaseB_I & AC current, inverter, Phase B & A Current probe & - \\
Inverter & PhaseC_I & AC current, inverter, Phase C & A & Current probe \\
Transformer & kW & Power, real & kW & Transformer \\
Transformer & kVAR & Power, reactive & kVAR Transformer
\end{tabular}


Table 21. Vibration Condition Monitoring System Data Elements ${ }^{a}$

\begin{tabular}{|c|c|c|c|c|}
\hline Location & Channel Name & Channel Purpose & Units & Sensor(s) \\
\hline Main bearing & ACC01 & Acceleration, UW main bearing $\left(0^{\circ}\right)$ & $\mathrm{m} / \mathrm{s}^{2}$ & Accelerometer \\
\hline Main bearing & ACC02 & Acceleration, DW main bearing $\left(0^{\circ}\right)$ & $\mathrm{m} / \mathrm{s}^{2}$ & Accelerometer \\
\hline Ring gear & ACC03 & Acceleration, planetary radial $45^{\circ}$ & $\mathrm{m} / \mathrm{s}^{2}$ & Accelerometer \\
\hline Ring gear & ACC04 & Acceleration, ring gear radial $135^{\circ}$ & $\mathrm{m} / \mathrm{s}^{2}$ & Accelerometer \\
\hline Ring gear & ACC05 & Acceleration, planetary radial $225^{\circ}$ & $\mathrm{m} / \mathrm{s}^{2}$ & Accelerometer \\
\hline Ring gear & ACC06 & Acceleration, ring gear radial $315^{\circ}$ & $\mathrm{m} / \mathrm{s}^{2}$ & Accelerometer \\
\hline Ring gear & ACC07 & Acceleration, planetary axial $0^{\circ}$ & $\mathrm{m} / \mathrm{s}^{2}$ & Accelerometer \\
\hline Generator & ACC08 & Acceleration, generator radial $0^{\circ}$ & $\mathrm{m} / \mathrm{s}^{2}$ & Accelerometer \\
\hline Main shaft & SPEED_PPM & Speed, main shaft hub bolts & PPM & Proximity switch \\
\hline Generator & CURRENT AMP & Current, generator cables & A & Current transducer \\
\hline
\end{tabular}

${ }^{a}$ Vibration condition monitoring system is stand-alone and provided by Romax Technology. 
Table 22. Dither Test Data Elements (10-Hz Continuous)

\begin{tabular}{|c|c|c|c|c|c|}
\hline Location & Channel Name & Channel Purpose & Units & Sensor(s) & Module \\
\hline DAS & MS Excel Timestamp & Time, MS Excel format, from Jan. 1, 1900 & $d$ & DAS & - \\
\hline DAS & LabVIEW Timestamp & Time, Labview format, from Jan. 1, 1904 & s & DAS & - \\
\hline Main shaft & LSS_Azimuth & Azimuth angle, conduit tube & deg. & Encoder & EC-CNT4 \\
\hline Main shaft & LSS_Speed & Speed, conduit tube & rpm & Calculated & - \\
\hline Planet A & PIN_A_BENDING & Strain, Planet Flex Pin A, bending & $\mathrm{mV} / \mathrm{V}$ & Strain gauge & \multirow{5}{*}{ NI 9237} \\
\hline Planet B & PIN_B_BENDING & Strain, Planet Flex Pin B, bending & $\mathrm{mV} / \mathrm{V}$ & Strain gauge & \\
\hline Planet C & PIN_C_BENDING & Strain, Planet Flex Pin C, bending & $\mathrm{mV} / \mathrm{V}$ & Strain gauge & \\
\hline Planet D & PIN_D_BENDING & Strain, Planet Flex Pin D, bending & $\mathrm{mV} / \mathrm{V}$ & Strain gauge & \\
\hline Planet A & PL_BRG_A_TEMP_LZ & Temperature, Journal Bearing A, load zone & ${ }^{\circ} \mathrm{C}$ & RTD & \\
\hline Planet A & PL_BRG_A_TEMP_NLZ & Temperature, Journal Bearing A, nonload zone & ${ }^{\circ} \mathrm{C}$ & RTD & \multirow{2}{*}{ NI 9217} \\
\hline Planet B & PL_BRG_B_TEMP_LZ & Temperature, Journal Bearing B, load zone & ${ }^{\circ} \mathrm{C}$ & RTD & \\
\hline Planet B & PL_BRG_B_TEMP_NLZ & Temperature, Journal Bearing B, nonload zone & ${ }^{\circ} \mathrm{C}$ & RTD & \\
\hline Planet C & PL_BRG_C_TEMP_LZ & Temperature, Journal Bearing $C$, load zone & ${ }^{\circ} \mathrm{C}$ & RTD & \multirow{4}{*}{ NI 9217} \\
\hline Planet C & PL_BRG_C_TEMP_NLZ & Temperature, Journal Bearing C, nonload zone & ${ }^{\circ} \mathrm{C}$ & RTD & \\
\hline Planet D & PL_BRG_D_TEMP_LZ & Temperature, Journal Bearing D, load zone & ${ }^{\circ} \mathrm{C}$ & RTD & \\
\hline Planet D & PL_BRG_D_TEMP_NLZ & Temperature, Journal Bearing D, nonload zone & ${ }^{\circ} \mathrm{C}$ & RTD & \\
\hline Planet A & PL_BRG_OIL_TEMP & Temperature, Oil Supply Planet A, manifold & ${ }^{\circ} \mathrm{C}$ & RTD & NI 9217 \\
\hline Planet A & PL_BRG_OIL_PRESS & Pressure, Oil Supply Planet A, manifold & PSI & Pressure & NI 9205 \\
\hline Torque tube & Gen_TQ1 & Torque, generator mechanical & $\mathrm{mV} / \mathrm{V}$ & Strain gauge & \multirow[t]{2}{*}{ NI 9237} \\
\hline Torque tube & Gen_TQ2 & Torque, generator mechanical & $\mathrm{mV} / \mathrm{V}$ & Strain gauge & \\
\hline Main bearing & MBT & Temperature, main bearing & ${ }^{\circ} \mathrm{C}$ & RTD & \multirow[t]{2}{*}{ NI 9217} \\
\hline Main bearing & BLT & Temperature, lubrication oil at main bearing & ${ }^{\circ} \mathrm{C}$ & RTD & \\
\hline Lube system & ISO_OIL_CLEAN & Oil cleanliness and particle counter & - & Hydac CSM 1220 & NI 9239 \\
\hline Lube system & ISO_1 & Oil cleanliness, Bin 1 & - & Hydac CSM 1220 & - \\
\hline
\end{tabular}




\begin{tabular}{lllll}
\hline Location & Channel Name & Channel Purpose & Units & Sensor(s) \\
\hline Lube system & ISO_2 & Oil cleanliness, Bin 2 & - & Hydac CSM 1220 \\
Lube system & ISO_3 & Oil cleanliness, Bin 3 & - & Hydac CSM 1220 \\
Lube system & Lube_Fan_Speed & Speed, lubrication cooler fan & rpm & Fan speed \\
Lube system & Lube_Flow_Calc & Flow rate, calculated from lubrication pump & LPM & - \\
Lube system & Lube_Manifold_Temp & Temperature, oil at distribution manifold & ${ }^{\circ}$ C & RTD \\
Lube system & Lube_Manifold_Pressure & Pressure, oil at distribution manifold & PSI & Pressure \\
Lube system & Lube_Flow_Meter & Flow rate, measured after lubrication pump & LPM & Flow meter \\
Lube system & Lube_Return_Temp & Temperature, oil from gearbox sump & ${ }^{\circ}$ C & RTD \\
NTL & Dither Actuator Displacement & Displacement, hydraulic actuator & mm & Proximity \\
NTL & Dither Actuator Force & Force, hydraulic actuator & $\mathrm{kN}$ & Load cell \\
\hline
\end{tabular}

